\title{
Corporate social reporting and assurance: The state of the art
}

\section{Isabel-María García-Sánchez ${ }^{a}$}

a) Instituto Multidisciplinar de Empresa (IME) y Departamento de Administración y Economía de la Empresa, Área de Economía Financiera y Contabilidad (Contabilidad), Facultad de Economía y Empresa, Campus Miguel de Unamuno s/n. 37007 Salamanca. España. https://orcid.org/0000-0003-4711-863

${ }^{a}$ Corresponding author.

E-mail address: lajefa@usal.es

\section{ART ICLE INFO}

Article history:

Received 10 January 2020

Accepted 9 March 2020

Available online 1 July 2021

\section{JEL classification:}

M12

M14

M49

Keywords:

Corporate social reporting

Corporate social disclosure

Sustainability reporting

Sustainability disclosure

Environmental reporting

Environmental disclosure

\section{Códigos JEL:}

M12
M14
M49

M49

Palabras clave:

Informes sociales de las empresas

Divulgación social de las empresas

Informes de sostenibilidad

Divulgación de la sostenibilidad

Divulgacion de la sostenibilic
Informes medioambientales

Informes medioambientales
Divulgación medioambiental

\begin{abstract}
A B S T R A C T
This research reviews the corporate social responsibility disclosure literature based on 330 articles that appeared between 2000 and 2019 in the 36 main journals in the Thomson Reuters InCities Journal Citation Reports categories of Business, Finance (Accounting), Management, Ethics and others related to Environmental Sciences/Planning and Development. The framework includes predictors of socially responsible disclosure and assurance related to individual, organizational and institutional factors, as well as impacts that we classify as external (i.e., market reactions) or internal (i.e., firm performance). In addition, we establish the moderator and mediator variables with a view to examining whether the relationship between social responsibility reporting/assurance services and its predictors and impacts change. The review reveals important research gaps that allow us to provide suggestions about future research in terms of empirical perspectives.
\end{abstract}

(C)2021 ASEPUC. Published by EDITUM - Universidad de Murcia. This is an open access article under the CC BY-NC-ND license (http://creativecommons.org/licenses/by-nc-nd/4.0/).

\section{Información social corporativa y aseguramiento: el estado de la cuestión RES U M EN}

Este trabajo realiza una revisión de la literatura sobre verificación y divulgación de información sobre responsabilidad social corporativa basada en 330 artículos publicados entre 2000 y 2019 en las 36 revistas principales indexadas en el Journal Citation Reports del Thomson Reuters InCities en las categorías de Business, Finance (Accounting), Management, Ethics y otras categorías relacionadas con Environmental Sciences/Planning and Development. El marco propuesto para el análisis se enfoca en los predictores de la verificación y divulgación de información social y medioambiental, categorizados en factores individuales, organizativos e institucionales; así como en los impactos, clasificándolos en externos (reacciones del mercado) o internos (resultado empresarial). Además, determinamos los moderadores y mediadores con el fin de examinar si la relación entre la verificación y la divulgación de información sobre responsabilidad social y sus predictores e impactos cambia. La revisión revela importantes lagunas en el estado actual de la investigación, permitiéndonos plantear sugerencias sobre futuras investigaciones.

(C)2021 ASEPUC. Publicado por EDITUM - Universidad de Murcia. Este es un artículo Open Access bajo la licencia CC BY-NC-ND (http://creativecommons.org/licenses/by-nc-nd/4.0/). 


\section{Introduction}

This article aims to answer the question "What do we know about sustainability disclosure and its external assurance?" To do so, we review existing articles; we examine the drivers and impacts, as well as the level of quality and credibility of corporate social responsibility (CSR) reporting and assurance by adopting a perspective based on qualitative analysis.

Previous literature about CSR reporting has approached this theme in different ways (Rodríguez-Gómez et al., 2020). For example, Moser \& Martin (2012) discussed CSR research in accounting and suggested two strategies to significantly benefit accounting researchers. Topics include information around two perspectives: (i) that firms should only engage in CSR activities when they maximize shareholder value; and (ii) firms should engage in CSR to benefit society. Additional topics include CSR disclosure and non-financial disclosure, CSR experiments and accounting studies.

According to Fifka (2013), in the 1970s and 1980s most of the literature was focused on Anglo-Saxon and western European countries. Nowadays, CSR reporting research has been focusing on both developed and developing countries. Fifka examined 186 studies in order to identify the determinants that were grouped according to the geographical origin of academics. This research supports the different approach of academics for empirically examining CSR disclosure, although there is a weak variation in results.

Similarly, in 2013 Hahn \& Kühnen examined 178 studies from 1999 to 2011. These articles were published in business, management and accounting journals. They review not only the adoption but also the extent and quality of CSR dissemination of information and identified a gap in theory, particularly regarding legitimacy, stakeholder, signalling and institutional paradigms. Huang \& Watson in 2015 also reviewed a list of studies from the 13 top journals of accounting by examining the predictors and impacts of CSR reporting.

Dienes, Sassen \& Fischer (2016) carried out a literature review about the effect that organization factors have on the development of CSR reports. Using a quality procedure, these authors evidenced for 316 papers published between 2000 and 2015 that the most important determinants are company size, media visibility, ownership structure and the existence of two specialized committees on the board, namely the audit and the CSR committees, although they observed contradictory effects of firm age, profitability, capital structure and board composition.

Analysing only studies in Chinese or English on environmental reporting, Yang, Craig \& Farley (2015) confirm the impact of a country's government on the dissemination of information, in addition to confirming the widespread adoption of the theory of agency in studies of the Chinese language and of institutional theory in those of the English language as theoretical sustenance.

Hahn, Reimsbach \& Schiemann (2015) focus on reviewing the literature on climate change, examining its determinants and effects and expanding the review towards issues of assurance and risks. These authors show how many of the previous studies are not linked to the theory.

In 2017, Ali, Frynas \& Mahmood also analysed the factors influencing voluntary reporting of CSR in 76 studies, including both developed and developing countries. These authors confirm that aspects such as size, sector of activity and profitability and aspects of corporate governance and country level act as predictors of sustainability reporting. In addition, the key factors vary depending on the development of the country. In developed countries, the concerns of domestic stake- holders are quite relevant, while in developing countries voluntary dissemination is more influenced by foreign stakeholders that exert greater power since in these countries companies receive less pressure from society.

Lodhia \& Hess (2014) explored CSR reporting in the mining sector from 2004 to 2013, but only considered the studies published in the Journal of Cleaner Production, evidencing the slow progress in these studies. Rodrigues \& Mendes (2018) also studied the mining sector, analysing 72 studies from the ISI Web of Knowledge. Using a content analysis, the authors identify two research streams in the mining industry: (i) relations with key stakeholders to gain legitimacy; and (ii) the need to improve the credibility and quality of sustainability information reported.

Cohen \& Simnett (2015) focus on sustainability assurance of CSR reports, accounting for external and internal perspectives. The authors propose multiple research opportunities/gaps in the assurance literature. In the same vein, Simnett, Carson \& Vanstraelen (2016) extensively review 130 studies about audits and assurance published between 1995 and 2014. Through this revision these authors support and confirm the evolution of research about these topics. This evolution involves the improvement and reinforcing of measures and proxies of audit quality, data sources and the method for controlling endogeneity. In addition, Simnett et al. (2016) propose challenges and research opportunities/gaps in audit and assurance.

More recently, Brooks \& Oikonomou (2018) focused their attention on the impact that CSR disclosures have on CSR and financial performance, including market parameters, and the relationship between these latest variables. The authors evidence positive effects for all relationships, although they are economically modest.

We believe that these literature revisions present several limitations associated with: (i) the aim of the study, normally focused on determinants (i.e., Dienes et al., 2016; Fifka, 2013; Frynas \& Mahmood, 2017), impacts (i.e., Brooks \& Oikonomou, 2018) or specific CSR dimensions, countries and industries (i.e., Reimsbach \& Schiemann, 2015; Rodrigues \& Mendes, 2018; Simnett et al., 2016; Yang et al., 2015); (ii) a focus on all journals without considering the academic relevance of these reviews (i.e., Hahn \& Kühnen, 2013) or only in specific reviews (i.e., Cohen \& Simnett, 2015; Huang \& Watson, 2015; Lodhia \& Hess, 2014). In addition, their aim is oriented toward evidencing a tendency in the determinants or impacts without considering the theoretical implications.

Thus, this literature review goes beyond previous studies and reviews the CSR disclosure and assurance literature based on 330 articles that appeared between 2000 and 2019 in the 36 main journals in the following Thomson Reuters InCities Journal Citation Reports categories: Business, Finance (Accounting); Management; Ethics; and others related to Environmental Sciences/Planning and Development. We adopt a qualitative approach for reviewing the predictors, impacts and moderating/mediating factors in CSR voluntary reporting. Our approach contributes to the previous literature in several respects. First, we consider a period of review of articles from 2000 to 2019, focusing on the most recent studies and, above all, the years of maximum publication on CSR reporting issues. Secondly, we do not limit ourselves to examining only predictors but also impacts, and we also consider those mediating and moderating variables that can modify the effect of the determinants and the consequences of CSR disclosure. Third, we consider the top 36 journals on the topic. We do not limit the journals to accounting, but also examine journals in management, ethics and other 
areas. Fourth, when examining these journals, we do not limit ourselves to studies of companies in specific countries. We do consider studies focused on a single country or region, but also international studies. Fifth, we present the main results of this paper classified according to topics and effect signs while indicating their practical and theoretical contributions.

The remainder of the literature review is structured as follows. In the next section (Section 1), we discuss the scope of the revision. Section 2 describes the quality and credibility of CSR disclosure from the reporting standards to the assurance information. Sections 3, 4 and 5 review the predictors, impacts and moderating/mediating factors in CSR reporting, respectively. Section 6 synthesizes the analysis for assurance. The concluding section (Section 7) discusses what is still unknown regarding CSR disclosure; in other words, important directions for future research are discussed.

\section{Scope of the review}

A systematic literature review requires a rigorous methodology that guarantees the identification of all the relevant articles and the right procedure for their review (Dienes et al., 2016). Thus, we have applied the scientific steps for any content analysis and, specifically, for the development of a bibliographical review:

- Clear determination of the research question of the literature review.

- Material recompilation, identifying the databases and the search criteria.

- Establishment of the review of the relevant papers according to structural categories that favour the classification of the main topics and the interpretation of the results and conclusions.

- Synthesizing the description of the formal aspects with regard to the selected papers in order to relate articles between them.

- Discussion of the findings of the literature review as regards what is known and what is not known and specification of future lines of research.

More specifically, the qualitative approach followed in this literature review around CSR disclosure and assurance issues has the following characteristics. First, we considered the papers published in the 36 main journals in the following Thomson Reuters InCities Journal Citation Reports categories: Business, Finance (Accounting); Management; Ethics; and others related to Environmental Sciences/Planning and Development. In addition, we included the four Spanish journals associated with the topic: the Spanish Journal of Finance and Accounting Revista Espanola de Financiacion y Contabilidad; the Spanish Accounting Review Revista de Contabilidad; the Business Research Quarterly Cuadernos de Economía y Dirección de Empresa; and the Revista Europea de Dirección y Economía de la Empresa (see Table 1).

Second, we used the editorial database to access our targeted journals and searched for relevant articles containing the phrases "corporate social disclosure", "corporate social reporting", "sustainability disclosure", "sustainability reporting", "environmental disclosure", "environmental reporting" or "assurance" in titles, abstracts, subjects or keywords. We focused on articles and excluded book reviews, replies and introductions to special issues.

Third, the period of analysis was from 2000 to 2019, a period during which the number of articles on these topics proliferated remarkably. The total number of studies examined was 330 .
Table 1

Journals examined

\begin{tabular}{|c|c|}
\hline Business, finance (Accounting) & Management \\
\hline Abacus & Business and Society \\
\hline Accounting Horizons & Business Strategy and the Environment \\
\hline Accounting and Finance & Business Research Quarterly \\
\hline The Accounting Review & Corporate Governance: An International \\
\hline Accounting, Organizations \& Society & Review \\
\hline $\begin{array}{l}\text { Accounting, Auditing \& Accountability } \\
\text { Journal }\end{array}$ & $\begin{array}{l}\text { Corporate Social Responsibility \& } \\
\text { Environmental Management }\end{array}$ \\
\hline \multirow{7}{*}{\multicolumn{2}{|c|}{$\begin{array}{ll}\text { Auditing: A Journal of Practice \& Theory } & \text { European Management Journal } \\
\text { British Accounting Review } & \text { European Management Review } \\
\text { Contemporary Accounting Review } & \text { International Business Review } \\
\text { Critical Perspective on Accounting } & \text { Long Range Planning } \\
\text { European Accounting Review } & \text { Organization \& Environment } \\
\text { Journal of Accounting \& Economics } & \text { Revista Europea de Dirección y Economía } \\
\text { Journal of Accounting and Public Policy } & \text { de la Empresa }\end{array}$}} \\
\hline & \\
\hline & \\
\hline & \\
\hline & \\
\hline & \\
\hline & \\
\hline \multirow{2}{*}{\multicolumn{2}{|c|}{$\begin{array}{l}\text { Journal of Accounting Research } \\
\text { Journal of Business Finance \& }\end{array}$}} \\
\hline & Ethics \\
\hline \multirow{4}{*}{$\begin{array}{l}\text { Accounting } \\
\text { Management Accounting Researc } \\
\text { Review of Accounting Studies } \\
\text { Spanish Journal of Finance and } \\
\text { Accounting }\end{array}$} & Business Ethics-A European Re \\
\hline & Business Ethics Quarterly \\
\hline & Journal of Business Ethics \\
\hline & Others \\
\hline \multirow{5}{*}{$\begin{array}{l}\text { Spanish Accounting Review } \\
\text { Sustainability, Accounting and } \\
\text { Management Policy Journal }\end{array}$} & Ecological Economics \\
\hline & Ecological Indicators \\
\hline & Environmental Policy and Governance \\
\hline & Journal of Cleaner Production \\
\hline & Sustainable Development \\
\hline
\end{tabular}

This paper presents a bibliographical review oriented toward impartial exposure of the research carried out on the disclosure of CSR information and its assurance. Analysis that is carried out according to objective criteria that have been accepted by the academy. More specifically, following the approach of Aguinis \& Glavas (2012), the procedure adopted in order to review the papers, relating them, discussing them and drawing conclusions about them, consisted in establishing two main subjects: CSR disclosures and assurances, with a special focus on their evolution and current state, and three subclassifications for research papers: (i) determinants of these practices, (ii) their impact and (iii) the moderating and mediating factors of drivers and consequences. Within each category, the order of the works is structured according to the topics addressed and the similarity between the results obtained. In the case of contradictory results, it is specified how they are analyzed in the later literature to determine or explain them.

The theoretical and empirical approach used in the work focused on the determining factors of CSR information disclosure and assurance practices and their level of quality will be analysed. In this regard, three levels will be considered: institutional pressures exercised at the country or sector level; organizational internal drivers; and individual psychological characteristics of the owners and managers.

In relation to the impacts, the studies will be addressed in terms of both their theoretical and practical approach, classifying the impacts of the disclosure of information and their assurance into two categories: external impact, related to the effect that information has on the capital market asymmetric information problems, cost of capital, analysts' predictions, etc.; and internal impact, related to the operational functioning and the company's strategic lines improvements in profitability, employee satisfaction, etc.

The moderating and mediating factors in relation to the disclosure of CSR information and assurance correspond to different types of intervening variables that modify the relationship between the disclosure/assurance and its predictors or impacts. The moderators act prior to the interaction between them, explaining which subjects and in what condi- 
tions the relationship between these two variables will take place. The mediators, for their part, act during the period of interaction of the variables, explaining how and why the relationship between these two variables occurs. In this regard, three levels will be considered: institutional, organizational and individual.

\section{Quality and credibility: From the reporting standards to the assurance information}

In recent years, and within an environment of high demand for information on the management approach and environmental, ethical and social performance of organizations, numerous companies have begun to publish sustainability or CSR reports; they offer information about their policies, commitments, activities and performance indicators related to their contribution to sustainable development (Mansell et al., 2020; Raucci and Tarquinio, 2020). This new reporting is aimed at meeting the new information requirements and demands of the stakeholders; however, it includes information of a quantitative and qualitative nature that makes it difficult to interpret the information it contains and its use in decision-making processes. In addition, several studies have shown that the information contained in these reports can present a high degree of subjectivity in their preparation, being of a less numerical nature and, therefore, less useful and comparable, for those companies that present sustainability practices that are less optimal than their competitors.

There is an abundant literature focused on determining the quality and usefulness of these reports prepared according to a standard, usually the Global Reporting Initiative Guidelines (GRI) for global sustainability reports and the recommendations of the Carbon Disclosure Project (CDP) for greenhouse gas (GHG) emissions. A critical review will be made of the degree of use of these standards and the deficiencies identified in their application high heterogeneity in the application of the GRI protocols, etc. Researchers have found evidence of the growth of social and environmental information disclosure throughout the world and across every industry examined (i.e., Albertini, 2014; Gibson \& O'Donovan, 2007; Higgins, Milne \& van Gramberg, 2015; Islam \& McPhail, 2011; Kolk \& Pinkse, 2010; Lauwo, 2016; Moneva \& Llena, 2000; Romolini, Fissi \& Gori, 2014; Russo-Spena, Tregua \& de Chiara, 2016; Secchi, 2006; Monteiro \& Aibar-Guzmán, 2010).

However, when the researchers analyse the opinion of the NGOs, they note that the relevance of CSR reports does not allow them to interact with the firms with the aim of improving sustainability practice (O'Dwyer, Unerman \& Hession, 2005). In the same vein, Fonseca, McAllister \& Fitzpatrick (2012) argue that managers believe it is necessary to promote important changes in legislative and regulatory frameworks in order to provide more accurate and relevant information on sustainability. In addition, research in Italy (Mio, 2010), Spain (Moseñe, Burritt, Sanagustín, Moneva \& Tingey-Holyoak, 2013), the Netherlands (Asif, Searcy, Santos \& Kensah, 2013) and Canada (Rodrigue, 2014) has identified important deficiencies in the disclosure of CSR, highlighting the need to improve compliance with international standards.

A major shortcoming is related to the materiality of the CSR reports and the inclusion and cooperation of stakeholders in them. Stakeholder participation is an essential process to align the objectives of the companies with their interests and identify the material content of the CSR reports. Manetti (2011), in this regard, finds that there is a stakeholder man- agement approach but not a stakeholder engagement approach. Similarly, Moratis \& Brandt (2017) found that more than half of the companies analysed did not provide detailed information on how the stakeholders participate in the content of the report; they also provided no information about how the companies responded to the concerns of the different company groups. In a similar vein, the findings of Herremans, Nazari \& Mahmoudian (2016) defend the dependence of resources of the stakeholders determines the relationships and resources destined to inform and involve them.

Another deficiency is that the revealed information is minimal and of low effectiveness and reliability, thereby limiting corporate transparency. Although some areas of CSR disclosure are well developed, others require significant improvements. Thus, even those companies that reveal a larger amount of quantitative/non-monetary information do not report all the CSR indicators necessary to know the company's environmental and social impact (Mio, 2010). In addition, Boiral \& Henri (2017), who compared the information disclosed in 92 GRI indicators, affirm the difficulty of measuring and rigorously comparing the CSR performance of the analysed companies belonging to the same sector, even when they strictly follow the same guidelines for reports, due to the qualitative, incomplete or ambiguous nature of the information, its opacity and the lack of compliance with the GRI protocols. Amini, Bienstock \& Narcum (2018), through a lexical content analysis of several Fortune 500 companies' CSR reports, identify three common issues - environment/energy, business and employees - that are disclosed with different emphasis across industries. Hossain, Momin, Rowe \& Quaddus (2017) find that Bangladesh firms disclose the highest amount of information about governance and community projects such as poverty alleviation activities, while human rights and workplace information is irrelevant, managerial decisions that try to reduce pressure from powerful stakeholders - investors and international buyers.

The above statements are observed more closely in the studies that analyse the different subtypes of social and environmental information. In this regard, Broadstock, Collins, Hunt \& Vergos (2018) evidence a disassociation between environmental and social responsibility disclosures. Kolk, Levy \& Pinkse (2008) observed that although a growing number of companies are responding to the recommendations of the CDP project, companies do not disclose detailed and useful information. In fact, Depoers, Jeanjean \& Jérôme (2016) argue that there is less information on GHG in the CSR report than in the CDP. Matisoff, Noonan \& O'Brien (2013) argue that the CDP has had mixed effects in improving transparency in the disclosure of emissions of certain scopes. Along the same lines, Kleinman, Kuei \& Lee (2017) analysed a sample of US food and beverage companies, showing a substantial divergence in the quality and scope of the content of disclosure about water. In addition, they observed that water consumption, water extraction, sustainable water management objectives and water quality strategy are the main topics addressed in all CSR reports. However, Leong, Hazelton, Taplin, Timms \& Laurence (2014) also report a lack of information on water storage capacity or water quality after recycling or reuse.

Adler, Mansi, Pandey \& Stringer (2017) explore biodiversity information revealed by the 50 leading mining companies from Australia before and after the United Nations (UN) declared the period 20112020 the "decade of biodiversity". There is a continuous growth in the number of biodiversity reports between 2010, before the declaration of the Union, and 2012 and 2013, after the declaration. However, the scope of the biodiversity reports is very unstable, identi- 
fying some companies that show substantial increases in the information revealed and others that show modest or no increases, disclosure practices that present high divergences between countries and industries (Skouloudis, Malesios \& Dimitrakopoulos, 2019; Smith, Paavola \& Holmes, 2019).

Aldaz Odriozola, Calvo Sánchez \& Álvarez Etxeberria (2012) analyse the most important Spanish companies, finding that the information they disclose about corruption refers to three general aspects related to anti-corruption policy, audit and control systems, and implementation mechanisms. The basic objective of these disclosures is to achieve legitimacy, even when the required specificity is not achieved with the disclosure. More precisely, Saenz \& Brown (2018), for a sample of construction firms that are located or operate in Latin America, evidence the relevance of topics associated with the commitment of leadership to anti-corruption practices and the development of monitoring systems. In contrast, information relating to the implementation and evaluation of policies and systems is less frequently disclosed. Likewise, Joseph et al. (2016) show the stage of "take-off" that the disclosure of anti-corruption practices is at in Indonesia and Malaysia, in addition to the disclosures especially oriented to codes of conduct against corruption.

Khan, Korac-Kakabadse, Skouloudis \& Dimopoulos (2019) conclude that the disclosures about people with disabilities in UK firms' reports are scarce, evidencing the lack of a stepping stone for their mainstreaming integration into labour markets. Lee \& Parpart (2018) contrast the inherently embedded meaning of CSR reports to evaluate the masculine tone of gender relations in these texts.

On the other hand, and as a consequence of the results of previous studies in which a lack of credibility regarding the CSR information is identified along with a reduced involvement of the stakeholders (i.e., Devenin \& Bianchi, 2018; Haller, van Staden \& Landis, 2016; Noronha, Leung \& Lei, 2015; Sharif Mahmud Khalid, Atkins \& Barone, 2019), a growing number of authors have begun to analyse the use that the companies make of the CSR information they release, arguing that they are efforts to legitimize themselves before society or to manipulate the opinion of different interest groups. In general, the results suggest practices of obfuscation in the information disclosed, which results in problems of comparability and verifiability.

Thus, it is worth noting the observations of Laine (2010), who states that pioneering companies in CSR reports disclose polyphonic information, using a fairly similar discourse for less sustainable behaviours. Morrison, Wilmshurst \& Shimeld (2016) indicate that the environmental reports of Tasmanian companies are based on utilitarianism and deontology, in contrast to the demands of external stakeholders, especially those with whom they have a less direct relationship. Similarly, Higgins and Coffey (2016) show that Australian companies use sustainability reports in a strategic way that allows them to obtain additional benefits in promoting dialogue with stakeholders.

O'Donovan (2002), interviewing six senior managers of three large companies, identified legitimacy as a key factor in voluntary disclosure on environmental issues, which also allows for improvement of corporate reputation. Years later, Hahn \& Lülfs (2014), analysing CSR reports of companies from the USA and Germany that follow the GRI guidelines, identified a legitimization strategy oriented in many cases toward modifying the perception of stakeholders. Boiral (2013) analysed the extent to which CSR disclosure could mask real problems in mining and energy companies, projecting an idealized vision of their performance. Subsequently,
Boiral (2016) showed that mining companies use different neutralization techniques when explaining their impact on biodiversity. Talbot \& Boiral (2015a, 2015b) reinforce the previous evidence, demonstrating that companies reveal increasingly opaque information over time, hiding data about the measures and the methodology utilized. The authors identify print management strategies that allow companies to justify certain information or hide it, applied in some of their analysis to information on climate change.

In a similar vein, Cho, Michelon \& Patten (2012) evidence enhancement (positive image) and obfuscation (negative trends) strategies in the use of graphs in CSR reports, although the enhancement practices are not necessarily associated with misleading information, practices that MartínezFerrero, Suárez-Fernández \& García-Sánchez (2018) confirm for information, showing that the worst CSR performance firms use quantity, syntactical and verbal tone and thematic content as impression management strategy. Zhihong Wang, Hsieh \& Sarkis (2018) confirm these results for readability. In addition, Hossain, Islam, Momin, Nahar \& Alam (2018) show that a high percentage of Fortune firms communicate their CSR performance in their reports in a fantasy and rhetorical manner, although their messages are different across countries of origin and other framework taxonomies.

Similarly, Lock \& Seele (2016) point out that the CSR reports issued by European companies are of low credibility, with much room for improvement, especially in relation to standardization. To be more credible, CSR reports need to be more understandable to users and, additionally, ensure their objectivity, specificity and truthfulness. Although this is not proven for mandatory standardization, voluntary standardization positively affects the credibility of CSR reports. Michelon, Pilonato \& Ricceri (2015) again point to the informative debate on the CSR reports.

\section{Predictors of CSR disclosure}

The present epigraph is focused on analysing the factors determining CSR information disclosure practices and quality. In this regard, three levels will be considered: institutional (pressures exercised at the country or sector level), organizational (internal drivers) and individual (psychological characteristics of the owners and managers).

\subsection{Institutional factors}

Several studies used institutional theory to explain CSR disclosure, a paradigm that considers companies to be economic organizations that operate daily in environments characterized by a nexus of institutions that impact on the firm's strategy and policies, leading to an isomorphism between organizations. It could be associated with mimicry when firms imitate the decisions of competitors; normative when firms perform in accordance with professional norms; and coercive when firms comply with rules due to fear of adverse consequences (García-Sanchez, Cuadrado-Ballesteros \& Frias-Aceituno, 2016). However, the studies adopted different approaches in order to observe the isomorphism in CSR disclosure.

Firstly, several papers have observed homogeneous disclosure practices through comparative analysis of different countries and/or industries. Lattemann, Fetscherin, Alon, Li \& Schneider (2009) raise the question of why there is lower CSR reporting of Chinese companies despite high CSR performance, and evidence different practices for India due to the fact that the governmental environment requires more 
disclosure. For their part, Fernández-Feijoo, Romero \& Ruiz (2014a) point out the leadership of European companies in the dissemination of CSR, proposing a double business approach: (i) a perspective of caution where less information is disseminated but with more credible information; and (ii) a leadership perspective where information is disseminated more often, and the information is more credible. Holland \& Foo (2003) defend, therefore, the influence on environmental performance and disclosure of the legal and regulatory framework of each country. In this regard, Chen \& Bouvain (2009) likewise note the differences in CSR efforts and their disclosure among countries. Young \& Marais (2012) found a higher level of CSR reporting in France than in Australia, and in high-risk industries a key factor regardless of the country. Likewise, Lock \& Seele (2015) confirm the sectoral difference regarding chemical companies vs banking and insurance industries.

Second, several papers focus their efforts on analyzing the role of coercion in isomorphism, focusing on the legal environment. Various studies confirm that countries' laws have a significant influence on CSR reporting. For instance, France required, starting in 2001, the publication of CSR reports. Chauvey, Giordano-Spring, Cho \& Patten (2015) show that even though there is low informational quality in CSR reporting, it has improved in recent years. The European Union, in Directive 2014/95/EU (of 22 October 2014) on non-financial disclosure, requiring mandatory non-financial information for large EU organizations that could play an important role towards higher integration of CSR within business models (Camilleri, 2015; La Torre, Sabelfeld, Blomkvist, Tarquinio \& Dumay, 2018). Maali, Casson \& Napier (2006) provide a further example of the impact of coercive pressure, finding that Islamic companies in the banking sector do not violate Islamic doctrine regarding human behaviour in the financial products they offer. Frost (2007), meanwhile, confirms the inclusion of environmental disclosure in response to obligatory guidances in Australia for some industries such as mining, oil, gas and paper. Along the same lines, Cowan \& Deegan (2011) analyse the changes in emissions disclosure after the National Inventory of Contaminants (NPI) was released, and show that these reports are still reactive, even though the information is not necessarily complete. On the other hand, Clarkson, Overell \& Chapple (2011), in their study of Australian companies, demand mandatory reports with a greater application and higher credibility of the information contained in them.

In contrast to the aforementioned results, in Spain, the Sustainable Economy Law 2/2011 made sustainability accounting mandatory for public sector bodies and large corporations. Larrinaga, Luque-Vílchez \& Fernández (2018) observed that did not have any effect in terms of quantity and quality of information disclosure by public organizations. In a similar vein, Larrinaga, Luque-Vílchez \& Fernández (2018) evidenced that did not have any impact in terms of the number of larger firms that disclose CSR reporting although the quality of information has increased slightly. Ma, Lee \& Goerlitz (2016) found considerably less compliance following the adoption of the California Transparency in Supply Chains Act. Originating in 2012, its aim was to avoid the slavery and human trafficking often associated with the supply chains of manufacturing and retail companies in the retail apparel and manufacturing industry. The results showed that $50 \%$ of the companies examined did not adopt it. In the same vein, firms from the UK must disseminate information about their GHG emissions and account for their climate change actions. According to Tang \& Demeritt (2017), firms disclose their emis- sions in response not only to regulatory compulsion but also to financial incentives and social pressure. In this regard, Beare, Buslovich \& Searcy (2014), through 35 interviews with senior employees, conclude that public policy does not influence CSR reporting. Meanwhile, Pedersen, Neergaard, Pedersen \& Gwozdz (2013) observe the positive effect that new governmental regulation has on Danish firms' CSR reports. However, the authors point out that in addition to coercive pressures, it is possible that organizations are largely imitating the behaviour of competitors for purposes of achieving standardization in sustainability disclosure.

Thirdly, other papers place a manifest focus on the influence of specific cultural, legal, socio-economic and other characterizations of environments on reporting or, as in Mallin, Michelon \& Raggi (2013), by the categorization of countries according to several stakeholder-oriented parameters. In this regard, Fifka \& Drabble (2012) confirm the effect on the CSR report's reach of sociocultural factors. Similarly, García Sánchez, Prado Lorenzo \& Frías Aceituno (2013) show the positive impact on CSR disclosure of the strength of the legal system civil law and ownership concentration. In addition, the frequency of reporting is higher when companies operate in countries with greater concern over CSR issues. All this favours the use of the GRI guide, a recognized international standard in the elaboration of CSR reports of superior quality and comparability. Gallego-Álvarez, Ortas, VicenteVillardón \& Álvarez Etxeberria (2017) confirm the difference in commitment to CSR disclosure depending on the country. Civil law countries focus on water and emissions while common law countries focus on materials and energy. GallegoÁlvarez \& Quina-Custodio (2017) found greater disclosure regarding CSR in countries with market economies led by the state particularly concerning stakeholder issues than in liberal economies. Pucheta-Martínez \& Gallego-Álvarez (2018) conclude that firms whose country of origin is characterized by high ownership dispersion are more likely to disclose environmental information. In contrast, investor protection is irrelevant. Dobbs \& van Staden (2016), for New Zealand companies, observed that shareholder rights and community concerns are the main drivers of CSR report decisions. Aranguren Gómez (2016), meanwhile, analyses a sample of German, Spanish and British companies and confirms the legal system and the aversion to uncertainty as key factors in the CSR disclosure strategy only when they focus on community and ethics issues. When focusing on employees, environment and consumers, sectoral pressures cancel out the effect of the above factors. Baldini, Maso, Liberatore, Mazzi \& Terzani (2016) also confirm the country effect, alluding to the political, labour and cultural system. Sethi, Martell \& Demir (2017a) again show how common law and strict standards and policies regarding CSR reporting are associated with higher quality in CSR reports.

With respect to specific cultural values, Prado Lorenzo, García Sánchez \& Blázquez Zaballos (2013) show that companies in countries with communitarian and feminist cultural systems tend to disseminate relevant information around CSR issues. Yusoff, Othman \& Yatim (2014), in their study of companies in Malaysia and Australia, confirm the effect of cultural values such as collectivism and high risk aversion on the perception of CSR disclosure. Moreover, there are differences between the two countries based on cultural and subcultural values. Similarly, García-Sánchez et al. (2016) found that companies located in more collectivist, feminist societies, with greater uncertainty avoidance and less power distance, favour the dissemination of CSR information. Luo, Tang \& Peng (2018), on the other hand, state that higher 
power distance negatively affects carbon disclosures and also acts as a moderating factor on the effect of carbon performance on transparency. By contrast, Gallén \& Peraita (2017) state that a society's degree of feminist values does not improve the quality of the information disclosed, and Rosati \& Faria (2019a) find that organizations disclosing about the sustainable development goals are more likely to be located in individualist countries. However, Cubilla-Montilla, Nieto-Librero, Galindo-Villardón, Vicente Galindo \& GarcíaSanchez (2019a) determine the limited role that the national cultural dimension will play in the evolution of those GRI indicators about human rights, society, labour practices and decent work, and product responsibility that are omitted more frequently from CSR reports. Results that also has been observed for the legal system in the paper of Cubilla-Montilla, Nieto-Librero, Galindo-Villardón, Vicente Galindo \& GarcíaSanchez (2019b).

Based on the foregoing, everything seems to indicate that the current practice is trending towards the standardization and homogenization of information from CSR reports. However, Higgins, Stubbs and Milne (2015) found that the disclosure of CSR information does not seem to be disseminated as an institutionalized practice that requires the company to interact and be considered part of the process. Shabana, Buchholtz \& Carroll (2016), in this regard, analyse the disclosure stages. First, a low CSR performance limits disclosure, but coercive pressures make it likely that the company will engage in some degree of disclosure. Subsequently, the benefits of this reporting are considered when sanctioned normatively. Finally, the pressure to mimic others' CSR disclosures makes the disclosure already generate a positive benefit-cost difference. In addition, Mazzi, Terzani, Baldini, Maso \& Liberatore (2016) evidence that institutional pressures play an heterogeneous inter- and intra-pillar impact on CSR disclosure, either enhancing or reducing information.

Fourth, and taking into account the sociopolitical economy and stakeholders' theories, previous studies focus on examining the influence of stakeholder pressures on the voluntary reporting of CSR information. Lu \& Abeysekera (2014), in their study of a sample in China, found a generally weak influence of stakeholders on social and environmental reporting, but shareholders and creditors were the exception to that rule and had a strong influence. Huang \& Kung (2010) found, in a Taiwanese study, that demands of both external stakeholders for instance, consumers, debtors and government and internal stakeholders, i.e. shareholders and employees, influence the scope of reporting. Chiu \& Wang (2015) found an impact of organizational donors on the global supply chain and of social contribution and rating agencies on the worlwide capital markets. Thijssens, Bollen \& Hassink (2015) analyse the substantial variation in CSR disclosure and its association with NGO power and legitimacy. Byun \& Kim (2017) also confirm the pressure of external stakeholders on the sustainability dissemination of information.

\subsection{Organizational factors}

In relation to organizational factors as determinants of the information dissemination strategy for CSR, previous studies coincide in pointing to the impact of business characteristics, such as size, profitability and sector. Thus, given the theoretical support of economic and sociopolitical theories, higher-visibility companies will disclose CSR information, improving their corporate reputation. Visibility is usually associated with size and sector-sensitive industries in regards to CSR issues (e.g., Branco \& Rodrigues, 2008; García-Sánchez, 2008; Thorne, Mahoney \& Manetti, 2014). Thus, Magness in
2006 suggested that the mining industry should be studied as one of the most visible in society and on which greater pressure is exerted in terms of CSR. However, Bini, Bellucci \& Giunta (2018) suggest that mining companies have adopted a selective and soft approach in CSR disclosures, using predominantly descriptive approaches for topics like human rights, opportunity and equality, recruitment and bargaining, and training, and omitting topics such as raw materials, waste, corruption and lobbying, and local employment. Dilling \& Harris (2018) evidence that the quality and quantity CSR information of Canadian energy and mining companies have increased, although relevant areas like risk management, responsible work practices, projects with high climate risk exposure, cost of energy, etc. are still at a low level. Cho, Laine, Roberts \& Rodrigue (2018), in contrast, state that oil and gas firms' CSR discourse about their environmental responsibilities confronts their proactive but less visible political strategies oriented toward simplifying the passage of the restrictive US norms concerning energy and good jobs. DeMiguel-Molina, Chirivella-González \& García-Ortega (2019) evidence that the CEO discourse in their letter is focused on demonstrating the importance of firms' philanthropic activities and the destinations effect of the investments for the communities in which firms operate with the aim of gaining their social licence to operate.

Thus far, the evidence is unclear about the impact of profitability on CSR reporting (e.g., Domench, 2003; Morhardt, 2010). Market capitalization has also been shown to be an essential factor in the disclosure of CSR issues (Cormier, Magnan \& Van Velthoven, 2005; Lee, 2017); risk and the age of fixed assets were both shown to have significant effects. In Malaysia, Amran, Ooi, Mydin \& Devi (2015) propose the effect of brand and corporate image. Reverte (2009), Sotorrío \& Sánchez (2010) and García-Ayuso \& Larrinaga (2003) all found a significant impact of media pressure, although Comyns (2016) did not.

These results are translated to other approaches to measure sustainability transparency, such as: the level of GRI adoption (e.g., Del Mar Alonso-Almeida, Llach \& Marimon, 2014; Kuzey \& Uyar, 2017), environmental accountability (e.g., Marco-Fondevila, Moneva Abadía \& Scarpellini, 2018), carbon disclosure (Rankin, Windsor \& Wahyuni, 2011), or the evolution of CSR disclosure in different countries like Sri Lanka (Dissanayake, Tilt \& Xydias-Lobo, 2016), South Africa (De Villiers, Low \& Samkin, 2014) and Mauritius (Mahadeo, Oogarah-Hanuman \& Soobaroyen, 2011).

However, in the last decade, enormous interest has developed in the role that the traditional guardians of financial reporting quality play in CSR disclosure: (i) the board of directors, the cusp of internal directive control mechanisms; and (ii) the ownership structure due to it could provoke the second agency problem, those relating to the expropriation of minority shareholders by majority ones, or could improve the monitoring process over managerial decisions. In addition, it is normal to analyse the effect associated with the presence of other typologies of owners. Nowadays, some papers are starting to analyse the effect of other monitoring mechanisms like Big4 (Pucheta-Martínez, Bel-Oms \& Rodrigues, 2019) and analyst coverage (Bernardi \& Stark, 2018b).

Prado-Lorenzo, Gallego-Álvarez \& García-Sánchez (2009) show that the power of the shareholders does not determine behaviour with regard to CSR reporting and the adoption of the GRI as a standard. Zeng, Xu, Yin \& Tam (2012) consider government ownership as a factor that tends to produce a higher level of CSR disclosure. Campopiano \& De Massis (2015) found that family-owned businesses had 
a higher level of sustainability disclosure than non-familyowned businesses. García-Torea, Fernández-Feijoo \& de la Cuesta-González (2017) examined ownership structure and CSR reporting in 128 listed firms from Spain. They showed a different relationship between each type of shareholder and the transparency of CSR information. Significant shareholders who are not directors have a positive effect on transparency. Conversely, firms with boards holding more than $25 \%$ of ownership are less transparent than holding companies with boards holding less than that threshold. They indicate the existence of information asymmetries between these two types of shareholders.

As regards the role of boards of directors, the first studies focus on demonstrating jointly the different characteristics of a board of directors that lead to greater transparency. Khan, Muttakin \& Siddiqui (2013) for Bangladeshi companies and Chan, Watson \& Woodliff (2014) for Australian companies confirm that firms disclose more CSR information when they have better corporate governance ratings. PradoLorenzo, Gallego-Álvarez \& García-Sánchez (2009) show a positive effect of board independence on the promotion of higher CSR transparency according to the recommendations of the GRI, and a negative effect of the diversity and the absence of impact of the reputation of the managers measured by the number of chairs they occupy on other boards. Jizi, Salama, Dixon \& Stratling (2013) found that CEO duality, the size of the board and independent directors on it protect the interests of shareholders and favour CSR disclosure in American banks. Rodríguez-Ariza, Frías Aceituno \& García Rubio (2014), Fuente, García-Sánchez \& Lozano (2017) and Kaymak \& Bektas (2017) also verify the positive effect of the size and diversity of the board of directors. Liao, Luo \& Tang (2015) confirm again the positive effect of board independence and diversity and the existence of the CSR committee on GHG emissions. However, this effect is not significant if the CSR committee is below a certain size, is independent and meets regularly. Similarly, Tauringana \& Chithambo (2015) found that the scope of CSR reporting is related to board size, managerial ownership and ownership concentration. In their study of South African companies, Ntim \& Soobaroyen (2013) show the negative repercussions of CSR reporting of institutional ownership but a positive impact of government property, board diversity, size and independence. However, CEO duality was not significantly related to CSR reporting.

Currently, studies are oriented toward more exhaustive analyses of the impact that each of the characteristics of a board has on the dissemination of information on CSR. Thus, there is a central investigation on gender diversity. For example, Fernández-Feijoo, Romero \& Ruiz-Blanco (2014) confirm the positive effect of diversity and of the board of directors. Hoang, Abeysekera \& Ma (2016) confirm the effect of diversity on Vietnamese listed companies. Hollindale, Kent, Routledge \& Chapple (2017) show that the quality of CSR is associated with the proportion of female board members. Ben-Amar, Chang \& Mcllkenny (2017) show the same relationship regarding information on climate change. Rosati \& Faria (2019b) determine that firms with a higher presence of female directors disclose higher information regarding the Sustainable Development Goals. García-Sánchez, SuárezFernández \& Martínez-Ferrero (2018) evidence the existence of positive externalities associated with female directors due to the fact that they reduce the managers' tendency of use impression management strategies on CSR disclosure, improving the balance, comparability and reliability of sustainability information, effects that are greater in companies located in more stakeholder-oriented environments. Cabeza-García,
Fernández-Gago \& Nieto (2017) found that a critical mass of three women on the board was needed to produce an effect. However, Furlotti, Mazza, Tibiletti \& Triani (2019) evidence that women empowerment is not always associated with greater transparency. In the same vein, the authors observed a positive impact of the presence of chairwomen on disclosure of gender policies, an effect that is not extensible to female CEOs.

In terms of board independence, Amran, Periasamy \& Zulkafli (2014), Muttakin \& Subramaniam (2015) and Muttakin, Khan \& Mihret (2018) evidence that increasing the presence of independent directors fosters the non-duality CEO that is associated with greater disclosure about climate change issues and CSR report quality, respectively. In contrast, Lamboglia, Paolone \& Mancini (2018) evidence that independents do not drive the implementation of environmental risk indicators. More precisely, Fernández-Gago, Cabeza-García \& Nieto (2018) complement previous findings, showing that those that improve the comparability of CSR information are independent directors with political backgrounds and diverse education. In addition, García-Sánchez \& Martínez-Ferrero (2018) point out that independent directors show an initial opposition to the voluntary disclosure of more comparable and relevant CSR information in order to constrain potential reputation risks. However, when firms' CSR performance is greater or firms that have been contracted an external assurance services of this report, they reject their initial posture.

Pucheta-Martínez, Bel-Oms \& Nekhili (2018) show that independent and female directors on boards drive CSR disclosure, a role that institutional directors do not play. This latest effect could be explained by the fact that institutional directors do not always act in an identical way. In the same vein, Pucheta-Martínez \& Chiva-Ortells (2018) evidence a curvilinear relationship between institutional-resistant directors and CSR information, disclosing that it is not significant for pressure-sensitive institutional directors. In addition, in a later study, Pucheta-Martínez, Bel-Oms \& OlcinaSempere (2018) contrast a quadratic relationship between institutional female directors and sustainability disclosures. García-Meca \& Pucheta-Martínez (2017) show how the relationship between institutional directors and CSR reporting depends on activity sectors. For instance, banks are more able to provide CSR reports in order to decrease the associated risk, while funds show a lower commitment to that because of the lower short-term benefits. More precisely, García-Sánchez, Rodríguez-Ariza, Aibar-Guzmán, \& AibarGuzmán (2020) show that the use of SDG Compass, a model that increases the relevance of information disclosed in relation to the 2030 Agenda, it is favored by the presence of foreign investors, pension funds and "other" investors. On the contrary, the government, financial institutions and cross holdings have no influenced non-financial information systems.

Meng, Zeng, Tam \& Xu (2013) found that CSR transparency is positively associated with the improvement of the strongest corporate governance mechanisms. Similarly, Peters \& Romi (2013) found that the existence of a CSR committee and a CFO of sustainability improves the transparency of CSR information disclosure. Amran, Lee \& Devi (2014), analysing the Asia-Pacific context, found that the strategic alliances developed by NGOs are positively associated with CSR disclosure strategy. Finally, Helfaya \& Moussa (2017) show that an effective strategy sponsored by CSR positively affects the quality but not the quantity of sustainability disclosure. 


\subsection{Individual factors}

Numerous previous studies have examined how the gender of managers, their academic formation, political ideology, leadership style, narcissism and reputation significantly influence the investments in CSR that they undertake. However, there are no specific articles aimed at determining the effect that the psychological characteristics of owners and managers exert on CSR reporting. Thus, we have considered as "individual factors of literature" those papers oriented toward examining the intrinsic motives that provoke business leaders to disclose or conceal better or worse CSR information.

In this respect, Cormier, Gordon \& Magnan (2004) examined the reflections of executives specialized in environmental issues in a sample of European and American companies. After this analysis, the authors pointed out the influence of executives' personal attitudes on the dissemination of information about CSR, which will be affected by the degree to which managers seek to satisfy the demands of stakeholders. On the other hand, Martin \& Hadley (2008), analysing large UK companies, point out that managers doubt the advantages associated with the disclosure of CSR partly because of the cost of data collection which limits their voluntary reporting. Along the same lines, Uddin, Siddiqui \& Islam (2018) found an association between socially responsible practices of financial institutions and personal incentives of managers and political parties; this accentuates the debate about the "ethics" of socially responsible investments. Bebbington, Higgins and Frame (2009) found that reputational advantages and commercial benefits are what motivate companies to voluntarily disclose their CSR information. Shafer \& Lucianetti (2018) find that CEOs' Machiavellian personality traits and economic ideology have a strong negative impact on social and environmental disclosures. Ben-Amar \& Belgacem (2018) observe that managers that engage in CSR for self-purposes try to mislead stakeholders about their decisions through complex narrative disclosures.

Recent literature has focused interest on the analysis of the effect that managers/shareholders' political connection has on CSR disclosures. Muttakin, Mihret \& Khan (2018), on the other hand, state that firms with corporate political connection revealed lower levels of CSR information due to firms considering that they could eschew stakeholder pressure for legitimacy threats associated with poor sustainability performance. In contrast, Zhi Wang, Reimsbach \& Braam (2018) find that politically connected firms are more likely to disclose CSR information than their counterparts.

Many papers focus on determining the ultimate managerial aim (unobservable) when they disclose CSR information. These articles distinguish two clearly opposed theoretical positions: the economic theory of voluntary disclosure of information and the sociopolitical theories of legitimization and stakeholders. The economic theory of voluntary disclosure of information proposes that there is a direct (positive) relationship between CSR performance and disclosure. This relationship, based on the cost theory of the owners, allows us to assume that companies with higher CSR performance will disclose it to obtain competitive advantages. The sociopolitical theories portray the disclosure of information as a mechanism to manipulate the perception that shareholders and stakeholders have about the company's performance, assuming a negative relationship between CSR performance and disclosure. Lower CSR performance is predicted to result in higher CSR disclosure for the purpose of masking true performance and modifying external opinions about the firm's commitment to CSR. Thus, companies with bad CSR perform- ance are encouraged to disclose CSR information qualitatively and with a notable lack of precision to alter stakeholders' perception of real CSR performance.

In this regard, Al-Tuwaijri, Christensen \& Hughes (2004) examine the possible interrelations between performance, disclosure and economic performance related to environmental issues. Clarkson, Li, Richardson \& Vasvari (2008) found that performance on environmental issues was positively related to its discretionary disclosure. Similarly, Braam, Uit De Weerd, Hauck \& Huijbregts (2016) found that GHG emissions and water consumption influence environmental disclosure. Giannarakis, Zafeiriou, Arabatzis \& Partalidou (2017) found that European firms with better environmental performance engage in greater disclosure of GHG information. Similarly, Radu \& Francoeur (2017) evidenced a positive impact of environmental performance on disclosure. And Ramos, Cecílio, Douglas \& Caeiro (2013) found Portuguese companies' disclosure practices to be related to environmental management and evaluation systems. Ott, Schiemann \& Günther (2017) indicate that the publication of information about GHG issues is closely related to superior performance in environmental actions.

Herbohn, Walker \& Loo (2014) and Hummel \& Schlick (2016) amplify this previous evidence. These authors examined the effect of CSR performance on disclosure, focusing on extractive industries from Australia. Jointly considering all papers, the results reveal that more sustainable firms disclose voluntary information of higher quality with the aim of transmitting information about high performance to the market as predicted by economic voluntary disclosure theories. Moreover, according to sociopolitical theories, companies with worse performance in CSR opt for disclosure of lower quality to mask their behaviour and protect the legitimacy of their actions in society.

\section{Impacts of CSR disclosure}

In general, it has been assumed that firms engage in CSR activities and disclose information about these practices because it is an important source of competitive advantage for several reasons: to obtain explicit return benefits such as market gains associated with a reduction of CSR-related risk; to acquire and maintain a stronger image and reputation; to more easily attract different resources; to improve operational performance by obtaining quality employees, thereby reducing cost savings; and to increase revenue from higher sales and market share because it is easier to create unforeseen opportunities between others.

In order to synthesize these potential benefits, the studies will be addressed from a theoretical and practical perspective, classifying the impacts of the disclosure of information into two categories: external impact, relating to the effect that disclosure has on the capital market, such as asymmetric information problems, cost of capital and analysts' predictions, and internal effects, related to operational functioning and the company's strategic lines improvements in profitability, employee satisfaction, etc.

In relation to internal effects, Spence (2009) analyses the extent to which CSR reporting favours engaging in dialogue with stakeholders. The results are based on interviews with UK investors and managers. The author finds that both believe firms are overwhelmingly the more relevant financial stakeholders with CSR disclosure and consider that this information should be only a mechanism whereby companies can communicate with them. Goettsche, Steindl \& Gietl (2016) found that the client's profile modifies the relevance 
and usefulness of sustainability reports, especially when business profitability is low. Bradford, Earp, Showalter \& Williams (2017) also analysed the usefulness of these reports to the consumer, showing how risk and compliance are the main issues valued by him/her (above the economic aspect). De Villiers \& Van Staden (2010) focus their study on Australia, the UK and the USA. They interview individually stakeholders and verify that the information on environmental issues requires more truthfulness. Hsueh (2016) found a lack of credibility of the stakeholders on CSR reports in family firms mainly due to the lack of veracity of the disclosed information.

Vigneau, Humphreys \& Moon (2015) analysed the process of adoption of the GRI standard and its consequences for the structure of the CSR committee and its management the design of the CSR actions and their time horizon and understanding of CSR performance. In the same vein, Rezaee \& Tuo (2017) found that the quantity of CSR disclosure impacts positively on earnings quality and negatively on discretionary earnings, mitigating unethical managerial behaviour relating to opportunistic reporting of financial statements. These results complement those observed by Martínez-Ferrero, GarcíaSanchez \& Cuadrado-Ballesteros (2015), who found that firms issuing a greater quality in their financial statements are in general more conservative and have less incentive to develop unethical accounting practices.

Weber (2014) argues that CSR disclosure influences both environmental and financial performance. Duff (2016) found that sustainability reporting leads to several benefits by informing about firms' legitimacy and reputation; it allows firms to reinforce their intellectual capital, to charge premium fees and improve partner wealth. Lawal, May \& Stahl (2017) and Platonova, Asutay, Dixon \& Mohammad (2018) found that both CSR actions and reports on them may potentially affect financial performance.

It has also been found that the adoption of standard GRI in the preparation of the reports which favours the credibility and comparability of the information affects business value but not investment decisions (Alazzani \& Wan-Hussin, 2013; Chiu, Lin \& Wang, 2017). Investors tend to positively value companies that issue CSR reports (Berthelot, Coulmont \& Serret, 2012), especially when the risk they assume in their investments is greater (Lackmann, Ernstberger \& Stich, 2012) and, relatedly, when economic uncertainty is higher.

Solomon, Solomon, Norton \& Joseph (2011), in this regard, argue that information on climate change is often required by institutional investors when designing their investment portfolios. Often, private reports compensate for the deficiencies found in mandatory and public information. Zamora-Ramírez, González-González \& SabaterMarcos (2016) focus on the information on climate change and GHG and analyse its relevance in the market, observing the importance it gives to this type of information. For Elliott, Grant \& Rennekamp (2017), the incentive to invest lies in the adjustment between the strategy framework and the presentation style of CSR reports. These authors found that investors perceive CSR information as a positive signal, thereby affecting their decision to invest. Meanwhile, Reimsbach \& Hahn (2015) also analyse the impact of disclosure on CSR in investment decisions. These authors observe that "negative" disclosure about CSR made by the company itself does not affect share price or investment decisions.

However, Solomon \& Solomon (2006) and Krasodomska \& Cho (2017) found that institutional investors do not value CSR disclosure when they take decisions about their portfolio investment, though it was considered useful. Murray,
Sinclair, Power and Gray (2006) find that there is not a direct association between share returns and CSR information. Similarly, Carnevale, Mazzuca \& Venturini (2012) found no evidence that investors attributed value relevance to banks' CSR disclosures worldwide. Moreover, in cross-country analysis, the authors observed that this reporting positively affects stock price in some countries, while in others it negatively affects it. Kolsi \& Attayah (2018) likewise found that CSR disclosure by public firms in an emerging stock market (ADX) had no impact on firm value as proxied by markettobook ratio. Brown-Liburd \& Zamora (2015), in an online experiment with 113 investors as participants, found that the investors' perceptions are higher when CSR investment is over the industry average, mediating the impact on their investment allocations. However, investors do not consider assurance a fairness heuristic.

These contradictory effects could be explained, as Guidry \& Patten (2010) and (Sankara, Patten \& Lindberg (2019) evidence, by the fact that market participants do not see value in the corporate choice to begin publishing a standalone CSR report, although they observed different market reactions with the quality of these disclosures. More specifically, Lu \& Abeysekera (2017) and Helfaya, Whittington \& Alawattage (2019) observed that users of CSR reports do not perceive quantity as the most important factor in determining sustainability information quality. They evaluate typologies of information and indicators reported, the adoption of reporting guidelines and the assurance statement, and they assign special relevance to the visual tools.

Meanwhile, Dhaliwal, Radhakrishnan, Tsang \& Yang (2012) analysed the impact of CSR reporting on the accuracy of analysts' forecasts, and found it to be stronger in stakeholder-oriented countries with lower financial transparency. Muslu, Mutlu, Radhakrishnan \& Tsang (2017) developed a score based on the readability, length, tone, and the horizon and numerical content of CSR narratives, and found that higher values are associated with higher analysts' forecast accuracy. Garrido-Miralles, Zorio-Grima \& GarcíaBenau (2016) found a negative relationship between absolute expected profit error and sustainability disclosures. Lee, Palmon \& Yezegel (2018) found that CSR reports have a negative effect on analysts' recommendation revisions and on the value of downgrade and upgrade revisions, all of them indicating that this information allows analysts to give more informative recommendations, limiting their role in the price discovery process. In this regard, Benlemlih, Shaukat, Qiu \& Trojanowski (2016) found a negative effect of CSR disclosure on total and idiosyncratic risk. Arayssi, Dah \& Jizi (2016) reveal that female directors promote social practices and disclosures about these topics, all of them reducing volatility of returns and systematic risk. Christensen (2016), in the same vein, found that such voluntary disclosure reduces the possibility of bribes or discrimination, for example. In addition, if such actions occur, the negative effect on the share price is lower. García-Sánchez, Aibar-Guzmán, AibarGuzmán Rodríguez-Ariza (2020) evidenced that the pessimistic (sell) recommendations made by analysts to investors favor the use of SDG Compass in order to inform about the implementation of business CSR strategies in accordance with the Sustainable Development Goals (SDGs). This effect occurs in a given year or in the year immediately following the analystst' sell recommendations. However, the SDG Compass strategy has only a short-term impact on later analysts' recommendations.

Expanding the literature, Armitage \& Marston (2008) confirm the reduction in the cost of capital when the company 
issues a CSR report. However, they also conclude that a high level of dissemination of information has been reached, and thus additional effects from greater disclosure are smaller. In addition, Clarkson, Fang, Li \& Richardson (2013) show that environmental disclosure provides useful information in the prison of corporate valuation regardless of the size. However, they did not obtain evidence of lower capital cost. Dhaliwal, Li, Tsang \& Yang (2014) do confirm the lower cost of capital as a result of the voluntary disclosure of CSR information, especially in stakeholder-oriented countries. Plumlee, Brown, Hayes \& Marshall (2015) showed that corporate value is highest when there is a high quality of voluntary environmental disclosure, in addition to confirming that the type and nature of disclosure are relevant and informative when establishing predicted relationships.

Gong, Xu \& Gong (2018) provide evidence that higher CSR disclosure quality, especially for GRI A level, offers incremental information beyond the credit ratings that allow firms to obtain lower costs of corporate bonds, to be subjected to less collateral terms, but more restrictive covenants. Relationships that are stronger in firms with weak corporate governance internal mechanisms and environments.

In line with previous findings, Odriozola \& Baraibar-Diez (2017) found that firms that disclose more quality CSR information have a better reputation; specifically, higher quality can reinforce the stakeholders' perceptions and thus the firm's reputation. Álvarez Etxeberria \& Aldaz Odriozola (2018) find that corruption issues in CSR reports bolster corporate reputation. Pérez, García de los Salmones \& López (2015) demonstrated that CSR disclosure is especially relevant and useful in improving corporations' reputations in the finance industry. As a consequence, this industry discloses significantly more CSR information than other sectors. Axjonow, Ernstberger \& Pott (2016) also find that CSR disclosure impacts on firms' reputation while also considering professional stakeholders. Arora \& Lodhia (2017) show how BP used CSR disclosure on its website (extensive information about its plans to solve the problem, but nothing about other social and environmental actions during the disaster) to manage its reputation risk arising from the environmental damage caused by the massive oil spill in the Gulf of Mexico. Finally, Heflin \& Wallace (2017) found that firms with greater CSR disclosure commitment are more able to address future environmental regulations and minimize the risk of environmental incidents.

\section{Moderating and mediating factors on predictors and impacts of CSR disclosure}

The moderating and mediating factors associated with CSR information reporting correspond to different types of intervening variables that modify the relationship between the disclosure and its predictors or impacts. The moderators act prior to the interaction between these two, influencing which subjects and in what conditions the relationship between these two variables will occur. The mediators, for their part, act during the period of interaction of the variables, accounting for how and why the relationship between these two variables occurs.

\subsection{Factors moderating and mediating the determinants of CSR disclosure}

Although most of the previously discussed studies contrast the positive relation between individual, organizational and institutional factors and CSR disclosure, an increasing number of articles are starting to analyse the moderating and mediating effects of various factors.

In this respect, the main finding of Luque-Vílchez, MesaPérez, Husillos \& Larrinaga (2019) is the positive impact that pro-environmental managers' personal values have on the quality of environmental disclosure, a relationship that is mediated by the firms' environmental organizational structures. In addition, Husillos, González \& Gil (2011) interviewed 30 executives of Spanish companies, who confirmed that internal and external factors are relevant to CSR information dissemination. Lozano, Nummert \& Ceulemans (2016) assert that there is a distinction between the impact of external and internal factors, arguing that the first disclosure of CSR reports results from a combination of internal motivations, while external factors favour the continuation of these reports.

García-Sánchez, Gómez-Miranda, David \& RodríguezAriza (2019a and 2019b) evidenced the mediating effect that CSR committee and assurance services play on the role that independents have on the adoption of the GRI_IFC performance standards, a disclosure strategy that improve corporate transparency.

Prado-Lorenzo \& García-Sánchez (2010), meanwhile, state that the board remains focused on the creation of value beyond responding to the demands of CSR performance and disclosure. Specifically, the results show that independent directors are not interested in higher transparency about GHG emissions in all scenarios. In contrast, female directors promote higher transparency, especially in those countries with higher stakeholder orientation. García-Sánchez \& Martínez-Ferrero (2017) analyse a sample of international data and confirm that the impact of board independence on CSR reporting is determined by the protection of investors and shareholders. The disclosure of CSR information results from a trade-off between the benefits and costs of disseminating proprietary disclosure. Mohamed Adnan, Hay \& van Staden (2018) show the effect that individualism (positive) and power distance (negative) cultural dimensions have on CSR reports, practices that are enhanced by the presence of a CSR committee, a mechanism that moderates part of the detrimental cultural influences on CSR reporting.

Cheng, Wang, Keung \& Bai (2017) analyse the moderating effect of ownership structure and regional development on voluntary disclosure of environmental issues, finding that there is a connection between politics and disclosure, especially in state-owned firms and in eastern and western regions of China. Similarly, Meng et al. (2013) also examined the influence of property on the performance-disclosure relationship in China. These authors confirm a complex relationship between the two constructs and the impact on the relationship of the ownership structure. Dawkins \& Fraas (2011) examined visibility as a moderating factor in the relationship, but did not find support for it. Luo (2017) examined the moderating impact of the institutional environment on the performance-disclosure relationship, focusing on carbon disclosure. However, Li, Huang, Ren, Chen \& Ning (2016) found that the impact of the search for legitimacy in carbon reporting is mediated by innovation in process but not by innovation in product. More recently, García-Sánchez, Oliveira \& Martínez-Ferrero (2020) observe the moderate the impact of female directors on gender reporting issues; Amorelli \& García-Sánchez (2020) find that a critical mass of three women on the board improve CSR disclsoure, could be reinforced this effect when the board's background, skills, and experience are greater and dissapiared when the chair of the 
board is a women. García-Sánchez, Aibar-Guzmán, AibarGuzmán \& Azevedo (2020) observe that the greater the ability of the CEOs, the greater the usefulness and comparability of CSR disclosures, and this relationship is moderate by the firmst' CSR performance.

\subsection{Factors moderating and mediating impacts of CSR dis- closure}

Several authors are starting to analyse the moderating and mediating roles that each institutional, organizational and individual factor could play in the effect that CSR disclosure has on companies' reputation, value, performance and so on.

The paper of García-Sánchez, Gómez-Miranda, David \& Rodríguez-Ariza (2019c) put the manifest the interrelations between disclosure strategies that improve corporate transparency, analysts, and forecast accuracy.

Hassan \& Ibrahim (2012) found that a higher firms' policy focus on stakeholder engagement, the existence of an environmental management system, and disclosure reports of specific environmental activities influenced the achievement of an environmental award. Moreover, the authors also found industry membership to be a moderator of this relationship.

Martínez-Ferrero, Ruiz-Cano \& García-Sánchez (2016) found a bidirectional relationship between CSR reporting and information asymmetries but only in stakeholderoriented countries. They also found that the institutional pressures associated with a stakeholder protection context are a significant moderating factor in this relationship. Wang, Cao \& Ye (2018) find that CSR disclosure, although it is mandatory, constrains earnings management in China, mitigating information asymmetry, and this effect is more relevant for companies with lower analyst coverage.

Malik \& Kanwal (2018) examined the relationship between CSR reports and firm performance in pharmaceutical firms located in Pakistan, finding that brand equity is a significant mediator of the relationship. In the same vein, Kaspereit \& Lopatta (2016) also support the positive link between sustainability reporting and firm value although they did not find support for the moderating role of value relevance. Li, Gong, Zhang \& Koh (2018) show whether higher CSR disclosure impacts on firm value due to improved accountability and stakeholder engagement. This effect is reinforced by CEO power, suggesting that stakeholders associate these disclosure with firms' greater commitment to CSR. Ni \& Zhang (2019) evidence that mandatory CSR reports reduce firms' dividend payouts significantly, suggesting the existence of positive benefits for stakeholders at the expense of shareholders. This is a negative relationship that is more pronounced for firms in which shareholders lack effective tools to protect themselves against pressures from stakeholders due to the presence of weaker corporate governance mechanisms. Yu \& Zheng (2018) and Yu, Kuo \& Kao (2017) determine that CSR disclosures suppose effective signals to stakeholders, provoking an increase in Chinese firms' competitive advantage, although customer concentration, environmental sensitivity and private/state ownership moderate this relationship.

Finally, Birkey, Guidry, Islam \& Patten (2016) confirm the negative reaction of markets when retail and manufacturing firms fail to make the disclosures required under the California Transparency in Supply Chains Act regarding their efforts on some human rights issues such as slavery and human trafficking. Moreover, a greater negative impact was found for larger firms and greater supply chain risks.

\section{Assurance of CSR disclosure}

In addition to correcting the mistrust that was being generated around CSR reports among their users, the leading companies in sustainability began to introduce new quality indicators in these reports through the hiring of a service of assurance or review of the non-financial information disclosed (Briem \& Wald, 2018; Maroun, 2019). The literature review would focus on those studies focused on the evolution of the verification-assurance services and the quality indicators created to determine the practices of assurance service professionals standards, scope, etc., so factors determining the impact of the information assurance service on CSR and its level of quality will be analysed. However, first it is necessary to identify those studies that focus on the development and status of assurance services.

In relation to the content of the assurance statements, evolution and implementation of assurance standards, Junior, Best \& Cotter (2014) analysed a sample of 250 people belonging to Fortune Global. These authors confirm that the number of companies that externally assure their CSR reports has increased in recent years, although it has stagnated after rapid growth. Similarly, Kuzey \& Uyar (2017) found an increase in the quality of CSR reporting among Turkish companies, although the external assurance process is not a common practice yet. Gillet-Monjarret (2018) evidenced that the practice of CSR reports assurance has evolved over time in France as a consequence of the introduction of a specific law, the Grenelle II Law. It promotes the standardization, increasing use of ISAE 3000 and the realization of a majority of these services by accounting professionals.

In a more sophisticated view, the early paper of Manetti \& Becatti (2009) analyses the relevance of assurance standards and confirms the need for specific guidelines for the assurer in the standard audit procedure. There are innovative elements included in national regulations that international ones ISAE 3000 or AA1000AS do not include, which are necessary for assurance quality. In a similar vein, Fonseca (2010) identifies other factors that may affect the quality of assurance. Among them are the assurance's scope and level, the interpretation of the requirements of the procedure and the diversity of the criteria used by assurers.

As a consequence of the evidence of these papers, the researchers started to analyse the different assurance statements for different assurance providers as well as assurance provider characteristics. Perego \& Kolk (2012) analysed assurance on an international level, and in addition to examining its prevalence, they also focused on parameters associated with the quality of the service, e.g., the type of assurance providers and the assurance standard. After their study, the authors confirmed the heterogeneity of assurance in its beginnings. Zorio, García-Benau \& Sierra (2013) examined the role of the type of assurer, finding that assurance quality is higher if the service is provided by an accountancy firm than by an engineering/consultancy firm. Sierra, Zorio \& GarcíaBenau (2013) show the domain on the assurance market of Big-4 firms. In this respect, Junior et al. (2014) suggest that the quality of assurance reports would be enhanced by adopting a mixed approach and the evaluation of stakeholders.

Ballou, Casey, Grenier \& Heitger (2012) also observed that accounting professionals provided higher-quality assurance. They also found that the capacity of identification and quantification of risks and economic data, and their independence, are the main factors associated with accounting firms' higherquality work. In addition, they found that although accountants do not usually promote CSR strategies, their participa- 
tion is strongly linked to its use, resulting in benefits for firms and stakeholders.

Larrinaga, Rossi, Luque-Vilchez \& Núñez-Nickel (2018), in a comparative study of the Italian and US assurance markets - two countries with the highest and lowest assurance activity evidence that the volume of the assurance statement is not different, although in Italy, the content is quite similar to the audit one due to the relevance of Big-4 services and the use of ISAE3000. In contrast, in the USA, the higher relevance of non-accountant assurers and lower CSR reports that were assured are associated with a higher variation in the content of assurance statements.

In addition, other papers have focused on the process by which sustainability assurance statements are applied and the materiality. In the same vein, O'Dwyer \& Owen (2005) question the independence of the assurance and the administrative control of it given the scarce or null participation of the stakeholder. However, the main finding in line with previous studies is the cautious and limited approach adopted by the accounting profession and the evaluative and supportive approach to the corporate strategy of non-accountants which may affect their independence. O'Dwyer (2011) highlights the process of trial and error by which accounting firms can increase their presence on the assurance market. They emphasize, thus, the difficulty of transferring the knowledge and the auditing technique to the assurance. The assurer offers more qualitative data. The insurer tries to carry out assurance services using tacit knowledge and "instinctive feelings". This has repercussions, as would be expected, in a high degree of subjectivity. O'Dwyer, Owen \& Unerman (2011) interviewed in depth several senior partners and other members directly engaged in sustainability assurance. Their purpose was to offer an analysis of the relationship between the pragmatic, moral and cognitive with three key assurance groups: clients, non-client users and the internal risk department. First, the authors point out that achieving this legitimacy requires adoption and the alignment of different strategies depending on the area they want to affect. Thus, obtaining legitimacy with clients implies getting a moral hard with non-client users, which in turn depends on getting a pragmatic view of the company's internal risk department. Canning, O'Dwyer \& Georgakopoulos (2019) analyse a case study how financial audit-styled concepts i.e., the flexibility and capacity to address the materiality of CSR data are transferred to assurance arenas; and how non-accounant assurers rationalize their intuition of structured audit methodologies.

Edgley, Jones \& Atkins (2015) examine the materiality of the assurers. They confirm that this materiality is affected by the participation of the stakeholders. In addition, the assurers adopt a more prospective rather than historical approach and are influenced by competitive logic, which also affects materiality and the interpretation of it. In the same vein, Moroney \& Trotman (2016) again examine the materiality and conclude that it is clearly influenced by the risk of breaching a contract and the impact of the community and therefore, by the sector of activity. As the authors point out, "understanding the factors that impact material judgments in sustainability reports is important because these factors affect the reliability of informed disclosure". Manetti \& Toccafondi (2012) focus on analysing the bonding of the assurer with the stakeholders. They confirm in this regard the effort to expand the participation of stakeholders in the assurance, although there are difficulties in the process.

Nowadays, in a similar vein to CSR reports, authors have started to analyse the impression strategies of assurance statement. Michelon et al. (2015) found that com- panies use assurance as a mechanism that avoids having to disclose information about higher-quality CSR. Boiral, Heras-Saizarbitoria \& Brotherton (2017) focus on examining the perception of the assurer \& the limitations of the service. They confirm the optimistic language of the assurer where they do not usually refer to problems and weaknesses of the CSR reports. In addition, this language is linked to a limited/moderate level of assurance. Boiral, HerasSaizarbitoria, Brotherton \& Bernard (2018) also confirm that ethical concerns are related to assurance due to their association with symbolic nature, commercialization and interdependence of services like the activities of assurance, auditing and consulting that assurers could realize in firms. In short, not only the independence of the assurer but also his or her impartiality are doubtful. In addition, Talbot \& Boiral (2015a) confirm the inefficacy of assurance in reinforcing the quality and representativeness of the data, disclosing ever more opaque data with little reference to measurements and methodologies used. They identify, therefore, strategies of impression management that makes it impossible for stakeholders to evaluate, control and compare the climatic performance of a company. However, Trotman \& Trotman (2015) contend that internal auditors demand verified processes that ensure the integrity and accuracy of the data. Finally, Kim, Green \& Johnstone (2016) demonstrate that auditors respond to the specific experience of multidisciplinary teams, even when the situation does not require such experience.

\subsection{Determinants}

Several studies have examined what determines the decision to contract an assurance service and the quality of that service. For example, Sierra et al. (2013) observe that assurance of CSR reporting and the selection of a Big-4 professional depend on the size, profitability, leverage and industry of the firm. In contrast, other papers have observed some differences from previous research. De Beelde \& Tuybens (2015) also confirm firm size and media visibility as two of the main factors in explaining their seeking CSR assurance. However, they observe a minimal impact of industry. In the same vein, Casey \& Grenier (2015) did not find any industry impact either. But they also support the influence of leverage; specifically, they report that highly leveraged firms show a lower predisposition to CSR assurance, maybe as a result of stringent bank monitoring.

Recent studies have examined several other determinants that can be classified into three levels: institutional (pressures exercised at the country or sector level), organizational (internal drivers) and individual (characteristics of the professional of the insurance service).

As regards institutional pressures, Fernández-Feijoo, Romero \& Ruiz-Blanco (2014) and Gallen \& Peraita (2017) found that the quality of CSR reports is greater in feminist countries. Martínez-Ferrero \& García-Sánchez (2017a) adopt an institutional approach to analyse the demand for assurance based on normative, coercive and mimetic factors. In this regard, the researchers confirm that the likelihood of assuring CSR reports is higher when firms operate in countries with strong cultural and legal systems and in industries with more commitment to CSR concerns. In addition, they confirm the supremacy of the normative factor with respect to the other pressures. Sethi, Martell \& Demir (2017b) link the quality of the CSR reporting to assurance in stakeholder-oriented countries and when there is high public pressure on CSR issues. Vaz Ogando, 
Ruiz Blanco \& Fernández-Feijoo Souto (2018) argue that stakeholder pressures determine the quality of assurance. Similarly, Fernández-Feijoo, Romero \& Ruiz (2014b) link the quality of CSR reporting to the pressure of customers, employees and the environment.

In relation to organizational factors, Prado-Lorenzo et al. (2009) was one of the first paper that included assurance as a factor in CSR reporting quality. The authors found that lower ownership concentration and shareholder power limit the adoption of the assurance. Meanwhile, Liao, Philip \& Yuyu (2016), in an empirical study of the assurance services in China, evidence that firms with a large board, non-duality CEO position and more female directors are more likely to engage in CSR assurance. In contrast, the background of the CEO, board independence and foreign directors do not play any role in the CSR assurance decision. Another factor is the relationship between audit committees and assurance. Kend (2015) and Al-Shaer \& Zaman (2018) find that, in the same vein as CSR committees, audit committee independence, expertise and oversight improve assurance services and explain the choice of a Big-4 as an assurer.

Martínez-Ferrero \& García-Sánchez (2018) analysed the level of assurance because of the attributes of the assurance provider, finding that the reputation and specialization effect of the assurer favours the probability of detecting material errors and omissions. When the assurer has more experience in providing audit services and greater knowledge and experience with the experts in the industry, they can issue opinions that are more precise, a finding that MartínezFerrero, García-Sánchez \& Ruiz-Barbadillo (2018) extend to assurance quality, with a score based on a content analysis approach with items related to the assurance statement format, assurance procedures, recommendations and opinions. In a similar vein, Fernández-Feijoo, Romero \& Ruiz (2018) report that assurance is more common in firms audited by a Big4 than those audited by other firms. In addition, the selection of a Big-4 as a financial auditor favours also being selected as an assurer. Muhammad \& De Villiers (2019) evidence that accounting assurers prefer to use ISAE3000, while nonaccountant assurance providers promote AA1000AS as a specialist standard among engineering workers and consultants day to day.

In relation to individual factors, in the same way as the disclosure of CSR, authors such as Hummel, Schlick \& Fifka (2017) show a negative impact of CSR performance on assurance decisions assuring the CSR report, the provision by accountants and the assurance scope. In addition, they found that participants in companies with lower CSR performance perform a wide range of assurance services in order to strengthen their internal processes and systems. Finally, they also found that accounting firms are associated with broader assurance statements.

\subsection{Impacts}

In relation to impacts, the studies will be addressed from their theoretical and practical approach, classifying the impacts of the insurance service into two categories: external and internal. External impact pertains to the effect that information has on the capital market asymmetric information problems, cost of capital and analysts' predictions. Internal impact is related to operational functioning and the company's strategic lines improvements in profitability, employee satisfaction, etc.

With respect to external effects, Pflugrath, Roebuck \& Simnett (2011) analyse the impact of the type of assurer (ac- countant vs non-accountant) on the credibility that financial analysts have in the reported information. The authors confirm that credibility is greater if accounting firms perform the assurance, although this impact also depends on the context. Positive influences include the company belonging to a sector where assurance is a common practice, and being located in the USA in the UK and Australia, there is hardly any difference between assurers. However, Kaspereit \& Lopatta (2016) did not evidence any effect on the perception of the agents in capital markets. In the same vein, Ferguson \& Pündrich (2015), analysing the mining industry, show no impact on the assurance market. Similar results are those of Cho, Michelon, Patten \& Roberts (2014), who evidence that attaining a thirdparty assurance on CSR reports does not suppose higher market value for USA firms.

Casey \& Grenier (2015), on the other hand, show that the assurance allows firms to obtain a lower cost of capital as a consequence of the lower analysts' forecast errors and dispersion. In addition, the cost of capital is lower when the assurer is from the accountancy profession. Martínez-Ferrero \& García-Sánchez (2017b) obtained the same results; that is, there is a lower cost of capital when the company verifies the CSR report and also when this service is provided by an accounting firm. Again, the evidence supports the reputational capital of accounting firms. Moreover, García-Sánchez, Hussain, Martínez-Ferrero \& Ruiz-Barbadillo (2019) state that, for an international database, the impact of assurance services on capital constraints, eases the access to finance.

Cheng, Green \& Ko (2015) focus on the impact on investment decisions of non-professional investors. These investors prefer to invest in those companies with higher CSR performance with an external assurance process; moreover, the effect is higher when CSR indicators are highly relevant for organization strategy.

Brown-Liburd \& Zamora (2015) find, furthermore, that investors may show scepticism about the information disclosed in terms of CSR, provided that the salary of the manager is linked to CSR performance. This link may lead to overinvestment in CSR in a discretionary manner. Thus, investors demand assurance as a mechanism that guarantees confidence and credibility in the disclosed information. Thereon, higher CSR performance leads to higher price share valuations when CSR reports have an assurance statement. However, in a later paper, Brown-Liburd, Cohen \& Zamora (2018) evidence that investors have higher fairness perceptions when firms' CSR investment is higher than the industry mean, but they do not use the CSR report assurance in a fairness heuristic. Reimsbach, Hahn \& Gürtürk (2017) determined that assurance positively affected professional investors' evaluation of a company's CSR performance, although the effect was conditional on the existence of a stand-alone CSR memory versus an integrated report, results that are nuanced by RivièreGiordano, Giordano-Spring \& Cho (2018), who observed that financial analysts are more likely to give positive opinions for companies with their environmental disclosure with no assurance statement than for companies that disclose environmental information with low-level assurance. Clarkson, Li, Richardson \& Tsang (2019) evidence that high CSR commitment companies are more likely to obtain assurance, also from a Big 4, and to adopt higher assurance scope. Decisions that increase the likelihood of inclusion in the DJSI. The type of assurance provider improves the market value of firms but not the inclusion in the sustainability index.

In relation to internal impacts, Steinmeier \& Stich (2017) show the significant positive role of CSR report assurance in managerial decisions like the efficiency of sustainability 
investments. This effect is greater for assurance services provided on a higher level and scope and it is a substitutive monitoring mechanism for those firms with other governance mechanisms that are weak. However, the evidence in favour of accountant assurers is weak.

In addition, Park \& Brorson (2005) clearly confirm the benefits associated with assurance, such as the development and improvement of internal information systems and the greater reliability of the information disclosed. Those companies that avoid adopting an assurance process hide behind its high cost and the possible lack of credibility even if the CSR report is assured. The authors argue that assurance will be promoted provided that the companies follow the path of the leading companies (a mimetic behaviour) and that internationally accepted assurance standards exist. In addition, assurance seeking will be driven by stakeholders' pressures, and will also depend on whether the company is able to identify the benefits associated with assurance.

Sierra-García, Zorio-Grima \& García-Benau (2015), meanwhile, positively link external assurance to the propensity for disclosing an integrated report. Braam et al. (2016), similarly, relate assurance to the probability of reporting information about environmental issues. However, firms usually report an incomplete image about how their strategy decisions and policies are made.

Specifically, Moroney, Windsor \& Aw (2012) verify that assurance positively influences a higher quality of information disclosed in terms of environmental issues. However, in those companies that assure their environmental report, there is no difference between the accountant and non-accountant assurers.

With a combined approach, Green \& Li (2011) link assurance to stakeholders' expectations and consider the influence of emitters and users of greenhouse gases. Among the stakeholders, the authors focus on emission preparers, emission insurers and shareholders. The results confirm the existence of a strong difference between the stakeholders and the responsibilities of the assurer and management. In addition, there is a gap in the credibility and usefulness that users attribute to assurance, particularly among users and emitters of greenhouse gases.

Recently researches have focused the effect of assurance services on the identification of mistakes in CSR reports due to the fact that they are more easily made and less likely to be identified than for financial information. Ballou, Chen, Grenier \& Heitger (2018) showed the existence of a competitive advantage of using accounting assurers due to the fact that they identify inaccuracies in previous reports, fomenting restatements, a practice that is also improved with the use of the GRI reporting framework. Accountants also prevent future reporting inaccuracies. More specifically, Michelon, Patten \& Romi (2018) find that the association is stronger for quantitatively non-material restatements, enabling the discovery of more error restatements than methodological update restatements. However, they obtain the opposite evidence for the typology of assurance provider.

\subsection{Moderating and mediating factors}

The moderating and mediating factors in relation to the verification of CSR information correspond to different types of intervening variables that modify the relationship between the assurance service and its predictor or impact. The moderators act prior to the interaction between the two, explaining with respect to which subjects and in what conditions the relationship between these two variables will take place. The mediators, for their part, act during the period of interaction of the variables, explaining how and why the relationship between these two variables occurs.

First, Peters \& Romi (2015) document that the likelihood of undertaking a CSR report and being charged to an accounting firm is determined by the existence of an environmental committee, but only if directors with extensive experience work there. In addition, in those companies with said committee and under environmental performance, the probability of assurance is lower. Zhou, Simnett \& Green (2016) focused on the assurance decision and the choice of the assurer. To do this, they considered factors of corporate governance and country level. Assuring a CSR report and the likelihood that this process will be provided by an accounting firm is more likely in companies that operate in countries oriented towards the stakeholders and less strict legal systems. Thus, the factors of corporate governance moderate this relationship between factors at the country level and assurance decisions.

Braam \& Peeters (2018) found that a high CSR performance positively influences the provision of assurance statements. Moreover, they found the shareholder-country orientation to be a moderating factor in the relationship between social and environmental performance and the choice of assurer. However, the stakeholder-country orientation plays a modelling role in the positive impact of high CSR performance on the decision to select a broader scope of assurance.

Lee, Park, Song \& Yook (2017) analyse the effect on the market value of environmental audits in a sample of Japanese companies. The authors conclude that the market value of the companies that implement these audits is greater than that of those that do not, and this effect is greater thanks to the interaction with the third-party guarantee.

Cuadrado-Ballesteros, Martínez-Ferrero \& García-Sánchez (2017) focus on the effect that assurance achieves in information asymmetries. Their results confirm that there are differences in the reduction of these asymmetries according to the type of assurer, especially in certain institutional contexts. More specifically, assurance is highly valued by investors located in stakeholder-oriented countries. However, in shareholder-oriented countries the assurance only manages to reduce information asymmetries when it is provided by accountants and with a reasonable/high level of assurance.

García-Sánchez \& Martínez-Ferrero (2017), finally, find support for the lower predisposition towards the CSR disclosure strategy of independent directors, except among firms with a higher cost of capital and lower proprietary costs; however, the main finding is that this lower commitment to CSR reporting is reduced by providing an assurance statement.

Mori Junior \& Best (2017) demonstrate that the content index model that was updated in G4 by the GRI allows stakeholders to understand the scope of the assurance services, improving the credibility of CSR reports.

\section{What we do not know: The research gap}

The study of the previous literature is realized through a bibliometric review, a bibliographic review, a meta-analysis, etc. In relation to the CSR disclosure and its assurance, papers, in general, focused on determinants or impacts of such corporate decisions, sometimes on very specific aspects of them (mining sector, impact on financial performance, etc.). This review jointly addresses determinants and impacts, as well as the mediators and moderators of both. In addition, previous studies are meta-analyses whose final objective is 
the establishment of a consensus evidenced on the impact and nature of the object of the review: for example, if the relationship between CSR disclosure and financial result is positive, negative or cannot be determined from the previous evidence. To do this, they can use statistical methods that make it possible to reach conclusions. Its focus is on the methodological level and the positive or negative nature of the relationship, leaving in a secondary plane the theoretical framework and the implications of the results achieved.

This paper addresses a bibliographic review oriented toward the impartial exposure of the research carried out on CSR disclosure and its assurance. We categorize the studies according to the accepted criteria within the academy, using, within each category, a sort according to the topics addressed and the similarity/divergence of the results obtained. In case of contradictory results, we specify how they are analyzed in the later literature to determine or explain these differences. Our approach allows the reader to easily identify future lines of research. That is to say, because our conclusions do not determine the relevance of the observed effect, but try to show if there are contradictions in the literature. We understand that we determine a gap that should be addressed in future research oriented toward analysing the reasons for these divergences, research that can be addressed through: (i) meta-analysis that evidences statistically the reasons for these divergences observed (i.e., Mar-Miras, Carrasco-Gallego \& Escobar-Perez, 2014); (ii) studies in new countries, sectors and periods of time; (iii) more comprehensive approaches to the determinants and impacts studied; and (iv) considering new mediators and moderator variables.

In addition, we discuss some of the plausible lines of research suggested by our review of the literature, highlighting research gaps and unexplored issues in the CSR reporting research in terms of quality, stakeholder perception, governance and regulation.

Our review of the literature on CSR reporting published between 2000 and 2019 suggests that despite the continuous growth in the number of CSR reports, they fail to meet the information needs of users because they do not provide complete, exhaustive or comparable information. At the international level, several studies show that companies disseminate CSR reports with limited information, particularly about how their firm's decisions regarding social and environmental issues are undertaken. One of the greatest weaknesses of the CSR disclosure process is that the information is compiled and prepared by the company itself, generating a debate on the reliability of the same and demanding external verification to ensure its credibility. Therefore, it is essential to know the commitment of each company in terms of CSR and the influence of the stakeholders on it. One of the main debates in recent years, based on the above, has been the credibility of CSR information and users' confidence in it.

Moreover, it is also necessary to consider the degree of adaptation of companies to the generally accepted standards for CSR reporting, the GRI guidelines. In particular, it is necessary to examine this variable in relation to the principle of materiality and stakeholders' participation. It is demanded, therefore, that regulatory bodies work on the development and promotion of general guidelines that clarify the content of these reports, as well as the format. Thus, future research should examine whether companies have begun to orient towards the dissemination of information of the highest quality based on the international standards for preparing such reports. In future studies, researchers should analyse in depth how the CSR report is used to involve stakeholders: for example, with regard to the gathering of comments from stake- holders and their participation.

In relation to CSR disclosure predictions, according to institutional theory, the results suggest that the disclosure of CSR information converges over time. In general, the results suggest that sustainability reporting consists of several dimensions and depends on complementary forces. However, it is necessary to analyse the role that these pressures could play in those typologies of CSR information that are less frequently disclosed.

In respect to organizational factors, it is necessary to analyse in depth whether powerful CEOs can affect the development of proactive CSR disclosure strategies in order to obtain benefits or, in contrast, to avoid the pressures of different stakeholders towards the possible discretionary use of a CSR reporting strategy that masks managers' reputational risks. In addition, it is necessary to follow up on previous research about the role that female and independent directors and other firm governance tools have in developing strategies aimed at meeting shareholders' and other stakeholders' requirements.

In regard to the factors that lead managers to favour CSR reporting actions, the previous literature agrees on the theoretical sustenance of the economic disclosure and sociopolitical theories. The latter argue that managers choose to promote CSR performance and disclosure strategies based on a quantitative approach in order to show society their leadership, but choose to adopt a qualitative approach to mask their low commitment to CSR and thereby guarantee the legitimacy of their actions.

Hence, future research needs to analyse whether firms should be encouraged to improve their CSR performance and reporting and if these practices enhance their brand names. In addition, it is important to examine whether the development of an integrated business sustainability strategy will improve CSR disclosure, in line with the opinion of managers who believe that the development and adoption of a certified standard, such as ISO 26001, may reduce environmental impact and reinforce CSR commitment and disclosure (Mitchell \& Hill, 2009).

In addition, as Ballou et al. (2012) indicate in their study, the accountancy profession does not usually collaborate with CSR strategies, but it would be necessary to examine whether their participation would be associated with benefits not only for the company but also for the different stakeholders. Thus, strategically integrating CSR actions could be of interest to accountancy and consultancy professionals when they market their advisory services on CSR issues.

Furthermore, if we consider that CSR reporting is related to a utility approach, trying to obtain CSR information of higher quality, scope and reliability has its starting point in the stakeholders' ability to put pressure on the organizations. It should be noted, in this regard, that coercive pressures have been replaced by mimetic forces imitation of the leading company to minimize the differences in CSR reporting. Future research should be oriented toward determining which institutional factors need to be improved in order to exert higher pressure on companies in order to obtain better CSR disclosure.

The controversy that previous studies highlight around the impact of CSR disclosure on firm value suggests future lines of research. Specifically, it is necessary to examine whether a sustainability disclosure strategy could reinforce corporate reputation, image, investors' confidence, profitability and so on. These future studies will yield the necessary evidence to confirm to top management that CSR disclosure is really necessary for a company and generates benefits in various 
financial, economic and market dimensions.

In addition, the development and publication of a sustainability report drives sustainability changes within and outside of the company. This leads to changes in data and indicators, strategy, organizational change, reputation and validation, stakeholders and the report itself. It is necessary to investigate these changes in more depth because they are part of the firm. Furthermore, additional tests could observe the mediators and moderators of the predictors-CSR disclosureimpacts relation in order to identify the different factors that affect the relationship between these variables. Identification of the moderators will allow us to highlight the interaction between independent and dependent variables, explaining in what subjects and in what conditions the relationship between these two variables will take place. The mediators, for their part, act during the period of interaction between the dependent and independent variables, explaining why the relationship between these two variables exists.

In relation to the status quo of external and voluntary assurance, the review of the previous literature allows us to affirm the following. There is a relatively new and incipient knowledge about the business characteristics of the organizations that externally verify their CSR memories, and also about the consequences of this service. Previous literature, although scarce, has also analysed the international assurance standards (e.g., ISAE 3000 and AAA1000). However, it is necessary to highlight that the national standards or guidelines have provided innovative elements not addressed in international standards. Nonetheless, they could be adopted or taken into consideration for the improvement of standards.

Moreover, from our point of view, future research should focus on: (i) explaining security levels (reasonable, limited or unsecured); (ii) analysing the scope (total or partial); (iii) determining the role of stakeholders within an interdisciplinary team; (iv) studying the independence of the assurer as well as the materiality of the information disclosed; and (v) developing the standardization and homogenization of assurance.

\section{Funding}

This research has received funding from the following entities:

- Ministerio de Ciencia e Innovación, Grant/Award Number: ECO2013-43838P.

- Ministerio de Ciencia, Innovación y Universidades, Grant/Award Number: RTI2018-093423-B-I00.

- Universidad de Salamanca, Grant/Award Number: USAL2017-DISAQ.

- Junta de Castilla y León y Fondo Europeo de Desarrollo Regional [Grant/Award No. CLU-2019-03 Unidad de Excelencia "Gestión Económica para la Sostenibilidad" (GECOS)].

\section{Conflict of interests}

The author declares no conflict of interests.

\section{References}

Adler, R., Mansi, M., Pandey, R., \& Stringer, C. (2017). United Nations Decade on Biodiversity: A study of the reporting practices of the Australian mining industry. Accounting, Auditing and Accountability Journal, 30(8), 1711-1745. https://doi.org/10.1108/ 09574090910954864

Aguinis, H., \& Glavas, A. (2012). What we know and dontt know Corporate Social Responsibility. Journal of Management, 38(4), 932-96

Alazzani, A., \& Wan-Hussin, W. N. (2013). Global Reporting Initiative's environmental reporting: A study of oil and gas companies. Ecological Indicators, 32, 19-24. https: //doi.org/10.1016/j.ecolind.2013.02.019

Albertini, E. (2014). A Descriptive Analysis of Environmental Disclosure: A Longitudinal Study of French Companies. Journal of Business Ethics, 121(2), 233-254. https://doi. org/10.1007/s10551-013-1698-y

Aldaz Odriozola, M., Calvo Sánchez, J. A., \& Álvarez Etxeberria, I. (2012). Divulgación de información sobre corrupción: Empresas del IBEX 35. Revista de Contabilidad, 15(1), 59-90. https://doi.org/10.1016/S1138-4891(12) 70038-9

Ali, W., Frynas, J. G., \& Mahmood, Z. (2017). Determinants of Corporate Social Responsibility (CSR) Disclosure in Developed and Developing Countries: A Literature Review. Corporate Social Responsibility and Environmental Management, 24(4), 273-294. https://doi.org/10.1002/csr. 1410

Álvarez Etxeberria, I., \& Aldaz Odriozola, M. (2018). The social reputation of European companies: Does anticorruption disclosure affect stakeholders' perceptions? Corporate Social Responsibility and Environmental Management, 25(5), 713-721. https://doi.org/10.1002/csr. 1488

Al-Shaer, H., \& Zaman, M. (2018). Credibility of sustainability reports: The contribution of audit committees. Business Strategy and the Environment, (March 2017), 1-14. https://doi.org/10.1002/bse.2046

Al-Tuwaijri, S. A., Christensen, T. E., \& Hughes, K. E. (2004). The relations among environmental disclosure, environmental performance, and economic performance: A simultaneous equations approach. Accounting, Organizations and Society, 29(5-6), 447-471. https://doi.org/10. 1016/S0361-3682(03)00032-1

Amini, M., Bienstock, C. C., \& Narcum, J. A. (2018). Status of corporate sustainability: a content analysis of Fortune 500 companies. Business Strategy and the Environment, 27(8), 1450-1461. https://doi.org/10.1002/bse.2195

Amorelli, M.F., \& GarcíaSánchez, I.M. (2020). Critical mass of female directors, human capital, and stakeholder engagement by corporate social reporting. Corporate Social Responsibility and Environmental Management. 27, 204221. https://doi.org/10.1002/csr.1793

Amran, A., Lee, S. P., \& Devi, S. S. (2014). The influence of governance structure and strategic corporate social responsibility toward sustainability reporting quality. Business Strategy and the Environment, 23(4), 217-235. https://doi.org/10.1002/bse.1767

Amran, A., Ooi, S. K., Mydin, R. T., \& Devi, S. S. (2015). The Impact of Business Strategies on Online Sustainability Disclosure. Business Strategy and the Environment, 24(6), 551-564. https://doi.org/10.1002/bse.1837

Amran, A., Periasamy, V., \& Zulkafli, A. H. (2014). Determinants of climate change disclosure by developed and emerging countries in asia pacific. Sustainable Development, 22(3), 188-204. https://doi.org/10.1002/sd.539

Aranguren Gómez, N. (2016). Divulgación de información social y medioambiental: un análisis de los patrones de comportamiento de empresas europeas cotizadas desde 
la teoría neo-institucional. Spanish Journal of Finance and Accounting / Revista Española de Financiación y Contabilidad, 45(2), 199-230. https://doi.org/10.1080/ 02102412.2016.1140393

Arayssi, M., Dah, M., \& Jizi, M. (2016). Women on boards, sustainability reporting and firm performance. Sustainability Accounting, Management and Policy Journal, 7(3), 376-401. https://doi.org/10.1108/ SAMPJ-07-2015-0055

Armitage, S., \& Marston, C. (2008). Corporate disclosure, cost of capital and reputation: Evidence from finance directors. British Accounting Review, 40(4), 314-336. https://doi.org/10.1016/j.bar.2008.06.003

Arora, M. P., \& Lodhia, S. (2017). The BP Gulf of Mexico oil spill: Exploring the link between social and environmental disclosure and reputation risk management. Journal of Cleaner Production, 140, 1287-1297. https: //doi.org/10.1016/j.jclepro.2016.10.027

Asif, M., Searcy, C., Santos, P. dos, \& Kensah, D. (2013). A Review of Dutch Corporate Sustainable Development Reports. Corporate Social Responsibility and Environmental Management, 20(6), 321-339. https://doi.org/10.1002/ csr. 1284

Axjonow, A., Ernstberger, J., \& Pott, C. (2016). The Impact of Corporate Social Responsibility Disclosure on Corporate Reputation: A Non-professional Stakeholder Perspective. Journal of Business Ethics. https://doi.org/10.1007/ s10551-016-3225-4

Baldini, M., Maso, L. D., Liberatore, G., Mazzi, F., \& Terzani, S. (2016). Role of Country- and Firm-Level Determinants in Environmental, Social, and Governance Disclosure. Journal of Business Ethics, 1-20. https://doi.org/10. 1007/s10551-016-3139-1

Ballou, B., Casey, R. J., Grenier, J. H., \& Heitger, D. L. (2012). Exploring the strategic integration of sustainability initiatives: Opportunities for accounting research. Accounting Horizons, 26(2), 265-288. https://doi.org/10.2308/ acch-50088

Ballou, B., Chen, P.-C., Grenier, J. H., \& Heitger, D. L. (2018). Corporate social responsibility assurance and reporting quality: Evidence from restatements. Journal of Accounting and Public Policy, (xxxx), 1-22. https://doi.org/10. 1016/j.jaccpubpol.2018.02.001

Beare, D., Buslovich, R., \& Searcy, C. (2014). Linkages between corporate sustainability reporting and public policy. Corporate Social Responsibility and Environmental Management, 21(6), 336-350. https://doi.org/ 10.1002/csr.1323

Bebbington, J., Higgins, C., \& Frame, B. (2009). Initiating sustainable development reporting: evidence from New Zealand. Accounting, Auditing \& Accountability Journal, 22(4), 588-625. https://doi.org/10.1108/ 09574090910954864

Ben-Amar, W., Chang, M., \& McIlkenny, P. (2017). Board Gender Diversity and Corporate Response to Sustainability Initiatives: Evidence from the Carbon Disclosure Project. Journal of Business Ethics, 142(2), 369-383. https: //doi.org/10.1007/s10551-015-2759-1

Ben-Amar, W., \& Belgacem, I. (2018). Do socially responsible firms provide more readable disclosures in annual reports? Corporate Social Responsibility and Environmental Management, 25(5), 1009-1018. https://doi. org/10.1002/csr.1517

Benlemlih, M., Shaukat, A., Qiu, Y., \& Trojanowski, G. (2016). Environmental and Social Disclosure and Firm Risk. Journal of Business Ethics, (June 2015), 1-14. https://doi.org/10.1007/s10551-016-3285-5

Bernardi, C., \& Stark, A. W. (2018). On the value relevance of information on environmental and social activities and performance - Some evidence from the UK stock market. Journal of Accounting and Public Policy, 37(4), 282-299. https://doi.org/10.1016/j.jaccpubpol.2018.07.001

Berthelot, S., Coulmont, M., \& Serret, V. (2012). Do Investors Value Sustainability Reports? A Canadian Study. Corporate Social Responsibility and Environmental Management, 19(6), 355-363. https://doi.org/10.1002/csr.285

Bini, L., Bellucci, M., \& Giunta, F. (2018). Integrating sustainability in business model disclosure: Evidence from the UK mining industry. Journal of Cleaner Production, 171, 1161-1170. https://doi.org/10.1016/j.jclepro.2017.09. 282

Birkey, R. N., Guidry, R. P., Islam, M. A., \& Patten, D. M. (2016). Mandated Social Disclosure: An Analysis of the Response to the California Transparency in Supply Chains Act of 2010. Journal of Business Ethics, 1-15. https: //doi.org/10.1007/s10551-016-3364-7

Boiral, O. (2013). Sustainability reports as simulacra? A counter-account of A and A+ GRI reports. Accounting, Auditing \& Accountability Journal, 26(7), 1036-1071. https://doi.org/10.1108/AAAJ-04-2012-00998

Boiral, O. (2016). Accounting for the Unaccountable: Biodiversity Reporting and Impression Management. Journal of Business Ethics, 135(4), 751-768. https://doi.org/10. 1007/s10551-014-2497-9

Boiral, O., \& Henri, J. F. (2017). Is Sustainability Performance Comparable? A Study of GRI Reports of Mining Organizations. Business and Society, 56(2), 283-317. https://doi.org/10.1177/0007650315576134

Boiral, O., Heras-Saizarbitoria, I., \& Brotherton, M. C. (2017). Assessing and Improving the Quality of Sustainability Reports: The Auditors' Perspective. Journal of Business Ethics, 1-19. https://doi.org/10.1007/s10551-017-3516-4

Boiral, O., Heras-Saizarbitoria, I., Brotherton, M.-C., \& Bernard, J. (2018). Ethical Issues in the Assurance of Sustainability Reports: Perspectives from Assurance Providers. Journal of Business Ethics, (0123456789). https://doi. org/10.1007/s10551-018-3840-3

Braam, G. J. M., Uit De Weerd, L., Hauck, M., \& Huijbregts, M. A. J. (2016). Determinants of corporate environmental reporting: The importance of environmental performance and assurance. Journal of Cleaner Production, 129, 724734. https://doi.org/10.1016/j.jclepro.2016.03.039

Braam, G., \& Peeters, R. (2018). Corporate Sustainability Performance and Assurance on Sustainability Reports: Diffusion of Accounting Practices in the Realm of Sustainable Development. Corporate Social Responsibility and Environmental Management, 25(2), 164-181. https: //doi.org/10.1002/csr.1447

Bradford, M., Earp, J. B., Showalter, D. S., \& Williams, P. F. (2017). Corporate sustainability reporting and stakeholder concerns: Is there a disconnect? Accounting Horizons, 31(1), 83-102. https://doi.org/10.2308/ acch-51639

Branco, M. C., \& Rodrigues, L. L. (2008). Social responsibility disclosure: A study of proxies for the public visibility of Portuguese banks. British Accounting Review, 40(2), 161-181. https://doi.org/10.1016/j.bar.2008.02.004

Briem, C. \& Wald, A. (2018). Implementing third-party assurance in integrated reporting: Companies' motivation and auditors' role. Accounting, Auditing \& Accountability Journal, 31 (5), 1461-1485. https://doi.org/10.1108/ 
AAAJ-03-2016-2447

Broadstock, D. C., Collins, A., Hunt, L. C., \& Vergos, K. (2018). Voluntary disclosure, greenhouse gas emissions and business performance: Assessing the first decade of reporting. British Accounting Review, 50(1), 48-59. https://doi.org/10.1016/j.bar.2017.02.002

Brooks, C., \& Oikonomou, I. (2018). The effects of environmental, social and governance disclosures and performance on firm value: A review of the literature in accounting and finance. British Accounting Review, 50(1), 1-15. https://doi.org/10.1016/j.bar.2017.11.005

Brown-Liburd, H., Cohen, J., \& Zamora, V. L. (2018). CSR Disclosure Items Used as Fairness Heuristics in the Investment Decision. Journal of Business Ethics, 152(1), 275289. https://doi.org/10.1007/s10551-016-3307-3

Brown-Liburd, H., \& Zamora, V. L. (2015). The role of corporate social responsibility (CSR) assurance in investors' judgments when managerial pay is explicitly tied to CSR performance. Auditing, 34(1), 75-96. https://doi.org/ 10.2308/ajpt-50813

Byun, H., \& Kim, T. H. (2017). Identity Claims and Diffusion of Sustainability Report: Evidence from Korean Listed Companies, 2003-2010. Journal of Business Ethics, 140(3), 551-565. https://doi.org/10.1007/ s10551-015-2669-2

Cabeza-García, L., Fernández-Gago, R., \& Nieto, M. (2017). Do Board Gender Diversity and Director Typology Impact CSR Reporting? European Management Review, (March 2007). https://doi.org/10.1111/emre.12143

Camilleri, M. A. (2015). Environmental, social and governance disclosures in Europe. Sustainability Accounting, Management and Policy Journal, 6(2), 224-242. https: //doi.org/10.1108/SAMPJ-10-2014-0065

Campopiano, G., \& De Massis, A. (2015). Corporate Social Responsibility Reporting: A Content Analysis in Family and Non-family Firms. Journal of Business Ethics, 129(3), 511-534. https://doi.org/10.1007/s10551-014-2174-z

Canning, M., O’Dwyer, B., \& Georgakopoulos, G. (2019). Processes of auditability in sustainability assurance-the case of materiality construction. Accounting and Business Research, 49(1), 1-27. https://doi.org/10.1080/00014788. 2018.1442208

Carnevale, C., Mazzuca, M., \& Venturini, S. (2012). Corporate Social Reporting in European Banks: The Effects on a Firm's Market Value. Corporate Social Responsibility and Environmental Management, 19(3), 159-177. https://doi.org/10.1002/csr.262

Casey, R. J., \& Grenier, J. H. (2015). Understanding and contributing to the enigma of corporate social responsibility (CSR) assurance in the United States. Auditing, 34(1), 97-130. https://doi.org/10.2308/ajpt-50736

Chan, M. C. C., Watson, J., \& Woodliff, D. (2014). Corporate Governance Quality and CSR Disclosure. Journal of Business Ethics, 125(1), 59-73. https://doi.org/10. 1007/s10551-013-1887-8

Chauvey, J. N., Giordano-Spring, S., Cho, C. H., \& Patten, D. M. (2015). The Normativity and Legitimacy of CSR Disclosure: Evidence from France. Journal of Business Ethics, 130(4), 789-803. https://doi.org/10.1007/ s10551-014-2114-y

Chen, S., \& Bouvain, P. (2009). Is corporate responsibility converging? a comparison of corporate responsibility reporting in the USA, UK, Australia, and Germany. Journal of Business Ethics, 87(SUPPL. 1), 299-317. https: //doi.org/10.1007/s10551-008-9794-0

Cheng, M. M., Green, W. J., \& Ko, J. C. W. (2015). The im- pact of strategic relevance and assurance of sustainability indicators on investors' decisions. Auditing, 34(1), 131162. https://doi.org/10.2308/ajpt-50738

Cheng, Z., Wang, F., Keung, C., \& Bai, Y. (2017). Will Corporate Political Connection Influence the Environmental Information Disclosure Level? Based on the Panel Data of A-Shares from Listed Companies in Shanghai Stock Market. Journal of Business Ethics, 143(1), 209-221. https://doi.org/10.1007/s10551-015-2776-0

Chiu, S. C., Lin, H. C., \& Wang, C. S. (2017). The Impact of Investments in Pollution Reduction on Shareholder Wealth: Evidence from Taiwanese Manufacturing Companies. Corporate Social Responsibility and Environmental Management, 24(6), 676-691. https://doi.org/ 10.1002/csr.1436

Chiu, T. K., \& Wang, Y. H. (2015). Determinants of Social Disclosure Quality in Taiwan: An Application of Stakeholder Theory. Journal of Business Ethics, 129(2), 379398. https://doi.org/10.1007/s10551-014-2160-5

Cho, C. H., Laine, M., Roberts, R. W., \& Rodrigue, M. (2018). The Frontstage and Backstage of Corporate Sustainability Reporting: Evidence from the Arctic National Wildlife Refuge Bill. Journal of Business Ethics, 152(3), 865-886. https://doi.org/10.1007/s10551-016-3375-4

Cho, C. H., Michelon, G., \& Patten, D. M. (2012). Enhancement and obfuscation through the use of graphs in sustainability reports: An international comparison. Sustainability Accounting, Management and Policy Journal, 3(1), 74-88. https://doi.org/10.1108/20408021211223561

Cho, C. H., Michelon, G., Patten, D. M., \& Roberts, R. W. (2014). CSR report assurance in the USA: An empirical investigation of determinants and effects. Sustainability Accounting, Management and Policy Journal, 5(2), 130148. https://doi.org/10.1108/SAMPJ-01-2014-0003

Christensen, D. M. (2016). Corporate accountability reporting and high-profile misconduct. Accounting Review, 91(2), 377-399. https://doi.org/10.2308/accr-51200

Clarkson, P. M., Fang, X., Li, Y., \& Richardson, G. (2013). The relevance of environmental disclosure: Are such disclosure incrementally informative? Journal of Accounting and Public Policy, 32(5), 410-431. https://doi.org/ 10.1016/j.jaccpubpol.2013.06.008

Clarkson, P. M., Li, Y., Richardson, G. D., \& Vasvari, F. P. (2008). Revisiting the relation between environmental performance and environmental disclosure: An empirical analysis. Accounting, Organizations and Society, 33(4-5), 303-327. https://doi.org/10.1016/j.aos.2007.05.003

Clarkson, P. M., Overell, M. B., \& Chapple, L. (2011). Environmental Reporting and its Relation to Corporate Environmental Performance. Abacus, 47(1), 27-60. https: //doi.org/10.1111/j.1467-6281.2011.00330.x

Clarkson, P., Li, Y., Richardson, G., \& Tsang, A. (2019). Causes and consequences of voluntary assurance of CSR reports: International evidence involving Dow Jones Sustainability Index Inclusion and Firm Valuation. Accounting, Auditing \& Accountability Journal, 32 (8), 24512474. https://doi.org/10.1108/AAAJ-03-2018-3424

Cohen, J. R., \& Simnett, R. (2015). CSR and assurance services: A research agenda. Auditing, 34(1), 59-74. https://doi.org/10.2308/ajpt-50876

Comyns, B. (2016). Determinants of GHG Reporting: An Analysis of Global Oil and Gas Companies. Journal of Business Ethics, 136(2), 349-369. https://doi.org/10. 1007/s10551-014-2517-9

Cormier, D., Gordon, I. M., \& Magnan, M. (2004). Corporate environmental disclosure: Contrasting manage- 
ment's perceptions with reality. Journal of Business Ethics, 49(2), 143-165. https://doi.org/10.1023/B:BUSI. 0000015844.86206.b9

Cormier, D., Magnan, M., \& Van Velthoven, B. (2005). Environmental disclosure quality in large German companies: Economic incentives, public pressures or institutional conditions? European Accounting Review, 14(1), 3-39. https://doi.org/10.1080/0963818042000339617

Cowan, S., \& Deegan, C. (2011). Corporate disclosure reactions to Australia's first national emission reporting scheme. Accounting and Finance, 51(2), 409-436. https: //doi.org/10.1111/j.1467-629X.2010.00361.x

Cuadrado-Ballesteros, B., Martínez-Ferrero, J., \& GarcíaSánchez, I. M. (2017). Mitigating information asymmetry through sustainability assurance: The role of accountants and levels of assurance. International Business Review, 26(6). https://doi.org/10.1016/j.ibusrev.2017.04.009

Cubilla-Montilla, M., Nieto-Librero, A.-B., Galindo-Villardón, M. P., Vicente Galindo, M. P., \& Garcia-Sanchez, I.-M. (2019a). Are cultural values sufficient to improve stakeholder engagement human and labour rights issues? Corporate Social Responsibility and Environmental Management, 1-18. https://doi.org/10.1002/csr.1733

Cubilla-Montilla, M., Nieto-Librero, A.-B., Galindo-Villardón, M. P., Vicente Galindo, M. P., \& Garcia-Sanchez, I.-M. (2019b). What companies do not disclose about their environmental policy and what institutional pressures may do to respect? Corporate Social Responsibility and Environmental Management, 1-17. https://doi.org/10.1002/ csr. 1874

Dawkins, C. E., \& Fraas, J. W. (2011). Erratum to: Beyond Acclamations and Excuses: Environmental Performance, Voluntary Environmental Disclosure and the Role of Visibility. Journal of Business Ethics, 99(3), 383-397. https://doi.org/10.1007/s10551-010-0659-y

De Beelde, I., \& Tuybens, S. (2015). Enhancing the credibility of reporting on corporate social responsibility in Europe. Business Strategy and the Environment, 24(3), 190-216. https://doi.org/10.1002/bse.1814

De-Miguel-Molina, B., Chirivella-González, V., \& GarcíaOrtega, B. (2019). CEO letters: Social license to operate and community involvement in the mining industry. Business Ethics, 28(1), 36-55. https://doi.org/10.1111/beer. 12205

De Villiers, C., \& Van Staden, C. J. (2010). Shareholders' requirements for corporate environmental disclosure: A cross country comparison. British Accounting Review, 42(4), 227-240. https://doi.org/10.1016/j.bar.2010.08. 002

De Villiers, C., Low, M., \& Samkin, G. (2014). The institutionalisation of mining company sustainability disclosure. Journal of Cleaner Production, 84(1), 51-58. https: //doi.org/10.1016/j.jclepro.2014.01.089

Del Mar Alonso-Almeida, M., Llach, J., \& Marimon, F. (2014). A closer look at the "Global Reporting Initiative" sustainability reporting as a tool to implement environmental and social policies: A worldwide sector analysis. Corporate Social Responsibility and Environmental Management, 21(6), 318-335. https://doi.org/10.1002/csr. 1318

Depoers, F., Jeanjean, T., \& Jérôme, T. (2016). Voluntary Disclosure of Greenhouse Gas Emissions: Contrasting the Carbon Disclosure Project and Corporate Reports. Journal of Business Ethics, 134(3), 445-461. https://doi. org/10.1007/s10551-014-2432-0

Devenin, V., \& Bianchi, C. (2018). Soccer fields? What for?
Effectiveness of corporate social responsibility initiatives in the mining industry. Corporate Social Responsibility and Environmental Management, 25(5), 866-879. https: //doi.org/10.1002/csr.1503

Dhaliwal, D. S., Radhakrishnan, S., Tsang, A., \& Yang, Y. G. (2012). Nonfinancial disclosure and analyst forecast accuracy: International evidence on corporate social responsibility disclosure. Accounting Review, 87(3), 723759. https://doi.org/10.2308/accr-10218

Dhaliwal, D., Li, O. Z., Tsang, A., \& Yang, Y. G. (2014). Corporate social responsibility disclosure and the cost of equity capital: The roles of stakeholder orientation and financial transparency. Journal of Accounting and Public Policy, 33(4), 328-355. https://doi.org/10.1016/j. jaccpubpol.2014.04.006

Dienes, D., Sassen, R., \& Fischer, J. (2016). What are the drivers of sustainability reporting? A systematic review. Sustainability Accounting, Management and Policy Journal, 7(2), 154-189. https://doi.org/10.1108/ SAMPJ-08-2014-0050

Dilling, P. F. A., \& Harris, P. (2018). Reporting on long-term value creation by Canadian companies: A longitudinal assessment. Journal of Cleaner Production, 191, 350-360. https://doi.org/10.1016/j.jclepro.2018.03.286

Dissanayake, D., Tilt, C., \& Xydias-Lobo, M. (2016). Sustainability reporting by publicly listed companies in Sri Lanka. Journal of Cleaner Production, 129, 169-182. https://doi.org/10.1016/j.jclepro.2016.04.086

Dobbs, S., \& van Staden, C. (2016). Motivations for corporate social and environmental reporting: New Zealand evidence. Sustainability Accounting, Management and Policy Journal, 7(3), 449-472. https://doi.org/10.1108/ SAMPJ-08-2015-0070

Domench, P. A. (2003). La Divulgación de la Información Social y Medioambiental de la Gran Empresa Española en el Período 1994-1998: Situación Actual y Perspectivas. Spanish Journal of Finance and Accounting / Revista Española de Financiación y Contabilidad, 32(117), 571-601. https://doi.org/10.1080/02102412. 2003.10779496

Duff, A. (2016). Corporate social responsibility reporting in professional accounting firms. British Accounting Review, 48(1), 74-86. https://doi.org/10.1016/j.bar.2014. 10.010

Edgley, C., Jones, M. J., \& Atkins, J. (2015). The adoption of the materiality concept in social and environmental reporting assurance: A field study approach. British Accounting Review, 47(1), 1-18. https://doi.org/10.1016/ j.bar.2014.11.001

Elliott, W. B., Grant, S. M., \& Rennekamp, K. M. (2017). How Disclosure Features of Corporate Social Responsibility Reports Interact with Investor Numeracy to Influence Investor Judgments. Contemporary Accounting Research, 34(3), 1596-1621. https://doi.org/10.1111/1911-3846. 12302

Ferguson, A., \& Pündrich, G. (2015). Does industry specialist assurance of non-financial information matter to investors? Auditing, 34(2), 121-146. https://doi.org/10. 2308/ajpt-50930

Fernandez-Feijoo, B., Romero, S., \& Ruiz, S. (2014a). Commitment to Corporate social responsibility measured through global reporting initiative reporting: Factors affecting the behavior of companies. Journal of Cleaner Production, 81, 244-254. https://doi.org/10.1016/j.jclepro. 2014.06.034

Fernandez-Feijoo, B., Romero, S., \& Ruiz, S. (2014b). Ef- 
fect of Stakeholders' Pressure on Transparency of Sustainability Reports within the GRI Framework. Journal of Business Ethics, 122(1), 53-63. https://doi.org/10. 1007/s10551-013-1748-5

Fernandez-Feijoo, B., Romero, S., \& Ruiz, S. (2018). Financial Auditor and Sustainability Reporting: Does it matter? Corporate Social Responsibility and Environmental Management, 25(3), 209-224. https://doi.org/10.1002/csr. 1449

Fernandez-Feijoo, B., Romero, S., \& Ruiz-Blanco, S. (2014). Women on boards: Do they affect sustainability reporting? Corporate Social Responsibility and Environmental Management, 21(6), 351-364. https://doi.org/10.1002/ csr. 1329

Fernández-Gago, R., Cabeza-García, L., \& Nieto, M. (2018). Independent directors' background and CSR disclosure. Corporate Social Responsibility and Environmental Management, 25(5), 991-1001. https://doi.org/10.1002/csr. 1515

Fifka, M. S. (2013). Corporate Responsibility Reporting and its Determinants in Comparative Perspective - a Review of the Empirical Literature and a Meta-analysis. Business Strategy and the Environment, 22(1), 1-35. https://doi. org/10.1002/bse.729

Fifka, M. S., \& Drabble, M. (2012). Focus and Standardization of Sustainability Reporting - A Comparative Study of the United Kingdom and Finland. Business Strategy and the Environment, 21(7), 455-474. https://doi.org/ 10.1002/bse.1730

Fonseca, A. (2010). How credible are mining corporations' sustainability reports? a critical analysis of external assurance under the requirements of the international council on mining and metals. Corporate Social Responsibility and Environmental Management, 17(6), 355-370. https://doi.org/10.1002/csr.230

Fonseca, A., McAllister, M. L., \& Fitzpatrick, P. (2012). Sustainability reporting among mining corporations: A constructive critique of the GRI approach. Journal of Cleaner Production, 84(1), 70-83. https://doi.org/10.1016/j. jclepro.2012.11.050

Frost, G. R. (2007). The introduction of mandatory environmental reporting guidelines: Australian evidence. Abacus, 43(2), 190-216. https://doi.org/10.1111/j. 1467-6281.2007.00225.x

Fuente, J. A., García-Sánchez, I. M., \& Lozano, M. B. (2017). The role of the board of directors in the adoption of GRI guidelines for the disclosure of CSR information. Journal of Cleaner Production, 141, 737-750. https://doi.org/10. 1016/j.jclepro.2016.09.155

Furlotti, K., Mazza, T., Tibiletti, V., \& Triani, S. (2019). Women in top positions on boards of directors: Gender policies disclosed in Italian sustainability reporting. Corporate Social Responsibility and Environmental Management, 26(1), 57-70. https://doi.org/10.1002/csr.1657

Gallego-Álvarez, I., \& Quina-Custodio, I. A. (2017). Corporate Social Responsibility Reporting and Varieties of Capitalism: an International Analysis of State-Led and Liberal Market Economies. Corporate Social Responsibility and Environmental Management, 24(6), 478-495. https://doi.org/10.1002/csr.1421

Gallego-Alvarez, I., Ortas, E., Vicente-Villardón, J. L., \& Álvarez Etxeberria, I. (2017). Institutional Constraints, Stakeholder Pressure and Corporate Environmental Reporting Policies. Business Strategy and the Environment, 26(6), 807-825. https://doi.org/10.1002/bse.1952

Gallén, M. L., \& Peraita, C. (2017). The Relationship between Femininity and Sustainability Reporting. Corporate Social Responsibility and Environmental Management, 24(6), 496-508. https://doi.org/10.1002/csr. 1423

García-Ayuso, M., \& Larrinaga, C. (2003). Environmental disclosure in Spain: Corporate characteristics and media. Revista Espanola de Financiacion y Contabilidad, 32(115 SPEC. ISSUE), 184-214. https://doi.org/10. 1080/02102412.2003.10779479

García-Meca, E., \& Pucheta-Martínez, M. C. (2017). How Institutional Investors on Boards Impact on Stakeholder Engagement and Corporate Social Responsibility Reporting. Corporate Social Responsibility and Environmental Management. https://doi.org/10.1002/csr.1451

García-Sánchez, I. M. (2008). Corporate social reporting: Segmentation and characterization of Spanish companies. Corporate Social Responsibility and Environmental Management, 15(4). https://doi.org/10.1002/csr.141

García-Sánchez, I.M., Aibar-Guzmán, B., Aibar-Guzmán, C., \& Azevedo, T. C. (2020). CEO ability and sustainability disclosures: The mediating effect of corporate social responsibility performance. Corporate Social Responsibility and Environmental Management. https://doi.org/10. 1002/csr.1905

García-Sánchez, I.M., Aibar-Guzmán, B., Aibar-Guzmán, C., \& Rodríguez-Ariza, L. (2020). "Sell" recommendations by analysts in response to business communication strategies concerning the Sustainable Development Goals and the SDG compass. Journal of Cleaner Production, 255 (2020) 120194.

García-Sanchez, I.-M., Cuadrado-Ballesteros, B., \& FriasAceituno, J.-V. (2016). Impact of the Institutional Macro Context on the Voluntary Disclosure of CSR Information. Long Range Planning, 49(1). https://doi.org/10.1016/j. lrp.2015.02.004

García-Sánchez, I.M., Gómez-Miranda, M.E, David, F. and Rodríguez-Ariza, L. (2019a). Board Independence and GRI-IFC performance standards: The mediating effect of the CSR committee. Journal of Cleaner Production, 225, 554-562.

García-Sánchez, I.M., Gómez-Miranda, M.E, David, F. and Rodríguez-Ariza, L. (2019b). The explanatory effect of CSR committee and assurance services on the adoption of the IFC Performance Standards, as a means of enhancing corporate transparency. Sustainability Accounting, Management and Policy Journal, forthcoming.

García-Sánchez, I.M., Gómez-Miranda, M.E, David, F. and Rodríguez-Ariza, L. (2019c). Analyst coverage and forecast accuracy when CSR reports improve stakeholder engagement: the GRI-IFC disclosure strategy. Corporate Social Responsibility \& Environmental Management, DOI: $10.1002 / \operatorname{csr} .1755$

García-Sánchez, I.-M., Hussain, N., Martínez-Ferrero, J., \& Ruiz-Barbadillo, E. (2019). Impact of disclosure and assurance quality of corporate sustainability reports on access to finance. Corporate Social Responsibility and Environmental Management, (January), 1-17. https://doi. org/10.1002/csr.1724

García-Sánchez, I. M., \& Martínez-Ferrero, J. (2017). Independent Directors and CSR Disclosure: The moderating effects of proprietary costs. Corporate Social Responsibility and Environmental Management, 24(1), 2843. https://doi.org/10.1002/csr.1389

García-Sánchez, I.-M., \& Martínez-Ferrero, J. (2018). How do Independent Directors Behave with Respect to Sustainability Disclosure? Corporate Social Responsibility and 
Environmental Management. https://doi.org/10.1002/ csr.1481

GarcíaSánchez, I.M., Oliveira, M.C., \& MartínezFerrero, J. (2020). Female directors and gender issues reporting: The impact of stakeholder engagement at country level. Corporate Social Responsibility and Environmental Management, 27, 369- 382. https://doi.org/10.1002/csr. 1811

García Sánchez, I. M., Prado Lorenzo, J. M., \& Frías Aceituno, J. V. (2013). Información social corporativa y sistema legal. Revista Europea de Dirección y Economía de La Empresa, 22(4), 186-202. https://doi.org/10.1016/j. redee.2012.11.003

García-Sánchez, I.M., Rodríguez-Ariza, L., Aibar-Guzmán, B., \& Aibar-Guzmán, C. (2020). Do institutional investors drive corporate transparency regarding business contribution to the sustainable development goals?. Business Strategy \& the Environment. https://doi.org/10.1002/ bse. 2485

García-Sánchez, I. M., Suárez-Fernández, O., \& MartínezFerrero, J. (2018). Female directors and impression management in sustainability reporting. International Business Review, 28(2), 359-374. https://doi.org/10.1016/j. ibusrev.2018.10.007

Garcia-Torea, N., Fernández-Feijoo, B., \& de la CuestaGonzález, M. (2017). The influence of ownership structure on the transparency of CSR reporting: empirical evidence from Spain. Spanish Journal of Finance and Accounting / Revista Española de Financiación y Contabilidad, 46(3), 249-271. https://doi.org/10.1080/ 02102412.2016 .1267451

Garrido-Miralles, P., Zorio-Grima, A., \& García-Benau, M. A. (2016). Sustainable Development, Stakeholder Engagement and Analyst Forecasts' Accuracy: Positive Evidence from the Spanish Setting. Sustainable Development, 24(2), 77-88. https://doi.org/10.1002/sd.1607

Giannarakis, G., Zafeiriou, E., Arabatzis, G., \& Partalidou, X. (2017). Determinants of Corporate Climate Change Disclosure for European Firms. Corporate Social Responsibility and Environmental Management. https://doi.org/10. 1002/csr.1461

Gibson, K., \& O’Donovan, G. (2007). Corporate governance and environmental reporting: An Australian study. Corporate Governance: An International Review, 15(5), 944956. https://doi.org/10.1111/j.1467-8683.2007.00615.

Goettsche, M., Steindl, T., \& Gietl, S. (2016). Do Customers Affect the Value Relevance of Sustainability Reporting? Empirical Evidence on Stakeholder Interdependence. Business Strategy and the Environment, 25(3), 149164. https://doi.org/10.1002/bse.1856

Gray, R., Javad, M., Power, D. M., \& Sinclair, C. D. (2001). Social and environmental disclosure and corporate characteristics: A research note and extension. Journal of Business Finance and Accounting, 28(3-4), 327-356. https: //doi.org/10.1111/1468-5957.00376

Green, W. J., \& Li, Q. (2011). Evidence of an expectation gap for greenhouse gas emissions assurance. Accounting, Auditing and Accountability Journal, 25(1), 146-173. https://doi.org/10.1108/09574090910954864

Gillet-Monjarret, C. (2018). Assurance reports included in the CSR reports of French firms: a longitudinal study. Sustainability Accounting, Management and Policy Journal, 9(5), 570-594. https://doi.org/10.1108/ SAMPJ-09-2017-0098

Gong, G., Xu, S., \& Gong, X. (2018). On the Value of Cor- porate Social Responsibility Disclosure: An Empirical Investigation of Corporate Bond Issues in China. Journal of Business Ethics, 150(1), 227-258. https://doi.org/10. 1007/s10551-016-3193-8

Guidry, R. P., \& Patten, D. M. (2010). Market reactions to the firsttime issuance of corporate sustainability reports. Sustainability Accounting, Management and Policy Journal, 1(1), 33-50. https://doi.org/10.1108/ 20408021011059214

Hahn, R., \& Kühnen, M. (2013). Determinants of sustainability reporting: A review of results, trends, theory, and opportunities in an expanding field of research. Journal of Cleaner Production, 59, 5-21. https://doi.org/10.1016/ j.jclepro.2013.07.005

Hahn, R., \& Lülfs, R. (2014). Legitimizing Negative Aspects in GRI-Oriented Sustainability Reporting: A Qualitative Analysis of Corporate Disclosure Strategies. Journal of Business Ethics, 123(3), 401-420. https://doi.org/10. 1007/s10551-013-1801-4

Hahn, R., Reimsbach, D., \& Schiemann, F. (2015). Organizations, Climate Change, and Transparency: Reviewing the Literature on Carbon Disclosure. Organization and Environment, 28(1), 80-102. https://doi.org/10.1177/ 1086026615575542

Haller, A., van Staden, C. J., \& Landis, C. (2016). Value Added as part of Sustainability Reporting: Reporting on Distributional Fairness or Obfuscation? Journal of Business Ethics, 1-19. https://doi.org/10.1007/ s10551-016-3338-9

Hassan, A., \& Ibrahim, E. (2012). Corporate Environmental Information Disclosure: Factors Influencing Companies' Success in Attaining Environmental Awards. Corporate Social Responsibility and Environmental Management, 19(1), 32-46. https://doi.org/10.1002/csr.278

Heflin, F, \& Wallace, D. (2017). The BP Oil Spill: Shareholder Wealth Effects and Environmental Disclosure. Journal of Business Finance \& Accounting, 44(3-4), 337374. https://doi.org/10.1111/jbfa.12244

Helfaya, A., \& Moussa, T. (2017). Do Board's Corporate Social Responsibility Strategy and Orientation Influence Environmental Sustainability Disclosure? UK Evidence. Business Strategy and the Environment, 26(8), 10611077. https://doi.org/10.1002/bse.1960

Helfaya, A., Whittington, M., \& Alawattage, C. (2019). Exploring the quality of corporate environmental reporting: Surveying preparers' and users' perceptions. Accounting, Auditing \& Accountability Journal, 32(1), 163-193. https://doi.org/http://dx.doi.org/10.1108/ 09564230910978511

Herbohn, K., Walker, J., \& Loo, H. Y. M. (2014). Corporate Social Responsibility: The Link Between Sustainability Disclosure and Sustainability Performance. Abacus, 50(4), 422-459. https://doi.org/10.1111/abac.12036

Herremans, I. M., Nazari, J. A., \& Mahmoudian, F. (2016). Stakeholder Relationships, Engagement, and Sustainability Reporting. Journal of Business Ethics, 138(3), 417435. https://doi.org/10.1007/s10551-015-2634-0

Higgins, C., \& Coffey, B. (2016). Improving how sustainability reports drive change: a critical discourse analysis. Journal of Cleaner Production, 136, 18-29. https://doi. org/10.1016/j.jclepro.2016.01.101

Higgins, C., Milne, M. J., \& van Gramberg, B. (2015). The Uptake of Sustainability Reporting in Australia. Journal of Business Ethics, 129(2), 445-468. https://doi.org/10. 1007/s10551-014-2171-2

Higgins, C., Stubbs, W., \& Milne, M. (2015). Is Sustainab- 
ility Reporting Becoming Institutionalised? The Role of an Issues-Based Field. Journal of Business Ethics, 147(2), 309-326. https://doi.org/10.1007/s10551-015-2931-7

Hoang, T. C., Abeysekera, I., \& Ma, S. (2016). Board Diversity and Corporate Social Disclosure: Evidence from Vietnam. Journal of Business Ethics, 1-20. https://doi. org/10.1007/s10551-016-3260-1

Holland, L., \& Foo, Y. B. (2003). Differences in environmental reporting practices in the UK and the US: The legal and regulatory context. British Accounting Review, 35(1), 1-18. https://doi.org/10.1016/S0890-8389(02) 00127-0

Hollindale, J., Kent, P., Routledge, J., \& Chapple, L. (2017). Women on boards and greenhouse gas emission disclosure. Accounting \& Finance, (December 2016). https: //doi.org/10.1111/acfi.12258

Hossain, M., Islam, M. T., Momin, M. A., Nahar, S., \& Alam, M. S. (2018). Understanding Communication of Sustainability Reporting: Application of Symbolic Convergence Theory (SCT). Journal of Business Ethics, 1-24. https: //doi.org/10.1007/s10551-018-3874-6

Hossain, M. M., Momin, M. A., Rowe, A. L., \& Quaddus, M. (2017). Corporate social and environmental reporting practices. Sustainability Accounting, Management and Policy Journal, 8(2), 138-165. https://doi.org/10.1108/ sampj-04-2015-0027

Hsueh, J. W. J. (2016). Governance Structure and the Credibility Gap: Experimental Evidence on Family Businesses' Sustainability Reporting. Journal of Business Ethics, 1-22. https://doi.org/10.1007/s10551-016-3409-y

Huang, C. L., \& Kung, F. H. (2010). Drivers of Environmental Disclosure and Stakeholder Expectation: Evidence from Taiwan. Journal of Business Ethics, 96(3), 435451. https://doi.org/10.1007/s10551-010-0476-3

Huang, X. B., \& Watson, L. (2015). Corporate social responsibility research in accounting. Journal of Accounting Literature, 34, 1-16. https://doi.org/10.1016/j.acclit.2015. 03.001

Hummel, K., \& Schlick, C. (2016). The relationship between sustainability performance and sustainability disclosure - Reconciling voluntary disclosure theory and legitimacy theory. Journal of Accounting and Public Policy, 35(5), 455-476. https://doi.org/10.1016/j.jaccpubpol.2016.06. 001

Hummel, K., Schlick, C., \& Fifka, M. (2017). The Role of Sustainability Performance and Accounting Assurors in Sustainability Assurance Engagements. Journal of Business Ethics, 4(17), 1-25. https://doi.org/10.1007/ s10551-016-3410-5

Husillos, J., González, C. L., \& Gil, M. J. Á. (2011). The emergence of triple bottom line reporting in Spain*/La aparición y desarrollo de las memorias de sostenibilidad en España. Revista Española de Financiación y Contabilidad, 40(150), 195-219. https://doi.org/10.1080/02102412. 2011.10779701

Islam, M. A., \& McPhail, K. (2011). Regulating for corporate human rights abuses: The emergence of corporate reporting on the ILO's human rights standards within the global garment manufacturing and retail industry. Critical Perspectives on Accounting, 22(8), 790-810. https: //doi.org/10.1016/j.cpa.2011.07.003

Jizi, M. I., Salama, A., Dixon, R., \& Stratling, R. (2013). Corporate Governance and Corporate Social Responsibility Disclosure: Evidence from the US Banking Sector. Journal of Business Ethics, 125(4), 601-615. https://doi. org/10.1007/s10551-013-1929-2

Joseph Joseph, C., Gunawan, J., Sawani, Y., Rahmat, M., Avelind Noyem, J., \& Darus, F. (2016). A comparative study of anti-corruption practice disclosure among Malaysian and Indonesian Corporate Social Responsibility (CSR) best practice companies. Journal of Cleaner Production, 112, 2896-2906. https://doi.org/10.1016/ j.jclepro.2015.10.091

Junior, R. M., Best, P. J., \& Cotter, J. (2014). Sustainability Reporting and Assurance: A Historical Analysis on a WorldWide Phenomenon. Journal of Business Ethics, 120(1), 1-11. https://doi.org/10.1007/s10551-013-1637-y

Kaspereit, T., \& Lopatta, K. (2016). The value relevance of SAM's corporate sustainability ranking and GRI sustainability reporting in the European stock markets. Business Ethics, 25(1), 1-24. https://doi.org/10.1111/beer. 12079

Kaymak, T., \& Bektas, E. (2017). Corporate Social Responsibility and Governance: Information Disclosure in Multinational Corporations. Corporate Social Responsibility and Environmental Management, 24(6), 555-569. https: //doi.org/10.1002/csr.1428

Khan, N., Korac-Kakabadse, N., Skouloudis, A., \& Dimopoulos, A. (2019). Diversity in the workplace: An overview of disability employment disclosures among UK firms. Corporate Social Responsibility and Environmental Management, 26(1), 170-185. https://doi.org/10.1002/ csr. 1669

Khan, A., Muttakin, M. B., \& Siddiqui, J. (2013). Corporate Governance and Corporate Social Responsibility Disclosure: Evidence from an Emerging Economy. Journal of Business Ethics, 114(2), 207-223. https://doi.org/10. 1007/s10551-012-1336-0

Kend, M. (2015). Governance, firm-level characteristics and their impact on the client's voluntary sustainability disclosures and assurance decisions. Sustainability Accounting, Management and Policy Journal, 6(1), 54-78. https: //doi.org/10.1108/SAMPJ-12-2013-0061

Kim, S., Green, W. J., \& Johnstone, K. M. (2016). Biased evidence processing by multidisciplinary greenhouse gas assurance teams. Auditing, 35(3), 119-139. https://doi. org/10.2308/ajpt-51368

Kleinman, G., Kuei, C., \& Lee, P. (2017). Using Formal Concept Analysis to Examine Water Disclosure in Corporate Social Responsibility Reports. Corporate Social Responsibility and Environmental Management, 24(4), 341356. https://doi.org/10.1002/csr.1427

Kolk, A., \& Pinkse, J. (2010). The Integration of Corporate Governance in Corporate Social Responsibility Disclosure. Corporate Social Responsibility and Environmental Management, 17(June 2010), 15-26. https:/ / doi.org/10. $1002 / \mathrm{csr}$

Kolk, A., Levy, D., \& Pinkse, J. (2008). Corporate responses in an emerging climate regime: The institutionalisation and commensuration of carborn disclosure. European Accounting Review, 17(4), 719-745. https://doi.org/10. $1080 / 09638180802489121$

Kolsi, M. C., \& Attayah, O. F. (2018). Environmental policy disclosure and sustainable development: Determinants, measure and impact on firm value for ADX listed companies. Corporate Social Responsibility and Environmental Management, (December 2017), 1-12. https://doi.org/ 10.1002/csr.1496

Krasodomska, J., \& Cho, C. H. (2017). Corporate social responsibility disclosure: Perspectives from sell-side and buy-side financial analysts. Sustainability Accounting, 
Management and Policy Journal, 8(1), 2-19. https://doi. org/10.1108/SAMPJ-02-2016-0006

Kuzey, C., \& Uyar, A. (2017). Determinants of sustainability reporting and its impact on firm value: Evidence from the emerging market of Turkey. Journal of Cleaner Production, 143, 27-39. https://doi.org/10.1016/j.jclepro. 2016.12.153

La Torre, M., Sabelfeld, S., Blomkvist, M., Tarquinio, L., \& Dumay, J. (2018). Harmonising non-financial reporting regulation in Europe: Practical forces and projections for future research. Meditari Accountancy Research, fothcoming

Lackmann, J., Ernstberger, J., \& Stich, M. (2012). Market Reactions to Increased Reliability of Sustainability Information. Journal of Business Ethics, 107(2), 111-128. https://doi.org/10.1007/s10551-011-1026-3

Laine, M. (2010). Towards sustaining the status quo: Business talk of sustainability in finnish corporate disclosure 1987-2005. European Accounting Review, 19(2), 247274. https://doi.org/10.1080/09638180903136258

Lamboglia, R., Paolone, F., \& Mancini, D. (2018). Determinants of the implementation of environmental risk indicators: Empirical evidence from the Italian manufacturing context. Corporate Social Responsibility and Environmental Management, (April 2018), 307-316. https: //doi.org/10.1002/csr.1680

Larrinaga, C., Luque-Vílchez, M., \& Fernández, R. (2018). Sustainability accounting regulation in Spanish public sector organizations. Public Money \& Management, 38(5), 345-354.

Larrinaga, C., Rossi, A., Luque-Vilchez, M., \& Núñez-Nickel, M. (2018). Institutionalization of the Contents of Sustainability Assurance Services: A Comparison Between Italy and United States. Journal of Business Ethics, 0(0), 0. https://doi.org/10.1007/s10551-018-4014-z

Lattemann, C., Fetscherin, M., Alon, I., Li, S., \& Schneider, A. M. (2009). CSR communication intensity in chinese and indian multinational companies. Corporate Governance: An International Review, 17(4), 426-442. https://doi. org/10.1111/j.1467-8683.2009.00758.x

Lauwo, S. (2016). Challenging Masculinity in CSR Disclosure: Silencing of Women's Voices in Tanzania's Mining Industry. Journal of Business Ethics, 1-18. https://doi. org/10.1007/s10551-016-3047-4

Lawal, E., May, G., \& Stahl, B. (2017). The Significance of Corporate Social Disclosure for High-Tech Manufacturing Companies: Focus on Employee and Community Aspects of Sustainable Development. Corporate Social Responsibility and Environmental Management, 24(4), 295-311. https://doi.org/10.1002/csr.1397

Lee, K. H. (2017). Does Size Matter? Evaluating Corporate Environmental Disclosure in the Australian Mining and Metal Industry: A Combined Approach of Quantity and Quality Measurement. Business Strategy and the Environment, 26(2), 209-223. https://doi.org/10.1002/bse. 1910

Lee, C., Palmon, D., \& Yezegel, A. (2018). The Corporate Social Responsibility Information Environment: Examining the Value of Financial Analysts' Recommendations. Journal of Business Ethics, 150(1), 279-301. https: //doi.org/10.1007/s10551-016-3197-4

Lee, K. H., Park, B. J., Song, H., \& Yook, K. H. (2017). The Value Relevance of Environmental Audits: Evidence from Japan. Business Strategy and the Environment, 26(5), 609-625. https://doi.org/10.1002/bse.1940

Lee, J., \& Parpart, J. L. (2018). Constructing gender identity through masculinity in CSR reports: The South Korean case. Business Ethics, 27(4), 309-323. https://doi.org/ 10.1111/beer.12191

Leong, S., Hazelton, J., Taplin, R., Timms, W., \& Laurence, D. (2014). Mine site-level water reporting in the macquarie and lachlan catchments: A study of voluntary and mandatory disclosure and their value for community decisionmaking. Journal of Cleaner Production, 84(1), 94-106. https://doi.org/10.1016/j.jclepro.2014.01.021

Li, D., Huang, M., Ren, S., Chen, X., \& Ning, L. (2016). Environmental Legitimacy, Green Innovation, and Corporate Carbon Disclosure: Evidence from CDP China 100. Journal of Business Ethics, 1-16. https://doi.org/ 10.1007/s10551-016-3187-6

Li, Y., Gong, M., Zhang, X. Y., \& Koh, L. (2018). The impact of environmental, social, and governance disclosure on firm value: The role of CEO power. British Accounting Review, 50(1), 60-75. https://doi.org/10.1016/j.bar. 2017.09.007

Liao, L., Luo, L., \& Tang, Q. (2015). Gender diversity, board independence, environmental committee and greenhouse gas disclosure. British Accounting Review, 47(4), 409-424. https://doi.org/10.1016/j.bar.2014.01.002

Liao, L., Philip, T., \& Yuyu, L. (2016). Corporate Board and Corporate Social Responsibility Assurance: Evidence from China. Journal of Business Ethics, (2015), 211-225. https://doi.org/10.1007/s10551-016-3176-9

Lock, I., \& Seele, P. (2015). Analyzing sector-specific CSR reporting: Social and environmental disclosure to investors in the chemicals and banking and insurance industry. Corporate Social Responsibility and Environmental Management, 22(2), 113-128. https://doi.org/10.1002/csr. 1338

Lock, I., \& Seele, P. (2016). The credibility of CSR (corporate social responsibility) reports in Europe. Evidence from a quantitative content analysis in 11 countries. Journal of Cleaner Production, 122, 186-200.

Lodhia, S., \& Hess, N. (2014). Sustainability accounting and reporting in the mining industry: Current literature and directions for future research. Journal of Cleaner Production, 84(1), 43-50. https://doi.org/10.1016/j.jclepro. 2014.08.094

Lozano, R., Nummert, B., \& Ceulemans, K. (2016). Elucidating the relationship between Sustainability Reporting and Organisational Change Management for Sustainability. Journal of Cleaner Production, 125, 168-188. https://doi.org/10.1016/j.jclepro.2016.03.021

Lu, Y., \& Abeysekera, I. (2014). Stakeholders' power, corporate characteristics, and social and environmental disclosure: Evidence from China. Journal of Cleaner Production, 64, 426-436. https://doi.org/10.1016/j.jclepro.2013.10. 005

Lu, Y., \& Abeysekera, I. (2017). What Do Stakeholders Care About? Investigating Corporate Social and Environmental Disclosure in China. Journal of Business Ethics, 144(1), 169-184. https://doi.org/10.1007/ s10551-015-2844-5

Luo, L. (2017). The influence of institutional contexts on the relationship between voluntary carbon disclosure and carbon emission performance. Accounting \& Finance, (November 2016). https://doi.org/10.1111/acfi.12267

Luo, L., Tang, Q., \& Peng, J. (2018). The direct and moderating effects of power distance on carbon transparency: An international investigation of cultural value and corporate social responsibility. Business Strategy and the Environment, 27(8), 1546-1557. https://doi.org/10.1002/ 
bse. 2213

Luque-Vílchez M. \& Larrinaga C. (2016). Reporting Models do not Translate Well: Failing to Regulate CSR Reporting in Spain. Social and Environmental Accountability Journal, 36(1), 56-75.

Luque-Vílchez, M., Mesa-Pérez, E., Husillos, J., \& Larrinaga, C. (2019). The influence of pro-environmental managers' personal values on environmental disclosure. Sustainability Accounting, Management and Policy Journal. https://doi.org/10.1108/sampj-01-2018-0016

Ma, Y. J., Lee, H. H., \& Goerlitz, K. (2016). Transparency of Global Apparel Supply Chains: Quantitative Analysis of Corporate Disclosure. Corporate Social Responsibility and Environmental Management, 23(5), 308-318. https: //doi.org/10.1002/csr.1378

Maali, B., Casson, P., \& Napier, C. (2006). Social reporting by Islamic banks. Abacus, 42(2), 266-289. https://doi.org/ 10.1111/j.1468-4497.2006.00200.x

Magness, V. (2006). Article information: Strategic posture, financial performance and environmental disclosure: An empirical test of legitimacy theory. Accounting, Auditing and Accountability Journal, 19(4), 540-563. https:// doi.org/link to this document: https://doi.org/10.1108/ 09513570610679128

Mahadeo, J. D., Oogarah-Hanuman, V., \& Soobaroyen, T. (2011). A Longitudinal Study of Corporate Social Disclosure in a Developing Economy. Journal of Business Ethics, 104(4), 545-558. https://doi.org/10.1007/ s10551-011-0929-3

Mansell, P., Philbin, S.P., \& Konstantinou, E. (2020). Redefining the Use of Sustainable Development Goals at the Organisation and Project Levels-A Survey of Engineers. Administrative Sciences, 10(3), 55; https://doi.org/10. 3390/admsci10030055

Malik, M. S., \& Kanwal, L. (2018). Impact of Corporate Social Responsibility Disclosure on Financial Performance: Case Study of Listed Pharmaceutical Firms of Pakistan. Journal of Business Ethics, 150(1), 69-78. https://doi. org/10.1007/s10551-016-3134-6

Mallin, C., Michelon, G., \& Raggi, D. (2013). Monitoring Intensity and Stakeholders' Orientation: How Does Governance Affect Social and Environmental Disclosure? Journal of Business Ethics, 114(1), 29-43. https://doi. org/10.1007/s10551-012-1324-4

Manetti, G. (2011). The quality of stakeholder engagement in sustainability reporting: Empirical evidence and critical points. Corporate Social Responsibility and Environmental Management, 18(2), 110-122. https://doi.org/ $10.1002 /$ csr.255

Manetti, G., \& Becatti, L. (2009). Assurance services for sustainability reports: Standards and empirical evidence. Journal of Business Ethics, 87(SUPPL. 1), 289-298. https: //doi.org/10.1007/s10551-008-9809-X

Manetti, G., \& Toccafondi, S. (2012). The Role of Stakeholders in Sustainability Reporting Assurance. Journal of Business Ethics, 107(3), 363-377. https://doi.org/10.1007/ s10551-011-1044-1

Marco-Fondevila, M., Moneva Abadía, J. M., \& Scarpellini, S. (2018). CSR and green economy: Determinants and correlation of firms' sustainable development. Corporate Social Responsibility and Environmental Management, (December 2017), 1-16. https://doi.org/10.1002/ csr. 1492

Maroun, W. (2019). Exploring the rationale for integrated report assurance. Accounting, Auditing \& Accountability Journal, 32 (6), 1826-1854. https://doi.org/10.1108/

\section{AAAJ-04-2018-3463}

Martin, A. D., \& Hadley, D. J. (2008). Corporate environmental non-reporting - A UK FTSE 350 perspective. Business Strategy and the Environment, 17(4), 245-259. https://doi.org/10.1002/bse.518

Martínez-Ferrero, J., \& García-Sánchez, I. M. (2018). The Level of Sustainability Assurance: The Effects of Brand Reputation and Industry Specialisation of Assurance Providers. Journal of Business Ethics, 150(4), 971-990. https://doi.org/10.1007/s10551-016-3159-x

Martínez-Ferrero, J., \& García-Sánchez, I.-M. (2017a). Coercive, normative and mimetic isomorphism as determinants of the voluntary assurance of sustainability reports. International Business Review, 26(1). https://doi.org/ 10.1016/j.ibusrev.2016.05.009

Martínez-Ferrero, J., \& García-Sánchez, I.-M. (2017b). Sustainability assurance and cost of capital: Does assurance impact on credibility of corporate social responsibility information? Business Ethics, 26(3). https://doi.org/10. 1111/beer.12152

Martínez-Ferrero, J., Garcia-Sanchez, I. M., \& CuadradoBallesteros, B. (2015). Effect of financial reporting quality on sustainability information disclosure. Corporate Social Responsibility and Environmental Management, 22(1). https://doi.org/10.1002/csr.1330

Martínez-Ferrero, J., García-Sánchez, I. M., \& RuizBarbadillo, E. (2018). The quality of sustainability assurance reports: The expertise and experience of assurance providers as determinants. Business Strategy and the Environment, 27(8), 1181-1196. https://doi.org/10.1002/ bse. 2061

Martínez-Ferrero, J., Ruiz-Cano, D., \& García-Sánchez, I.-M. (2016). The Causal Link between Sustainable Disclosure and Information Asymmetry: The Moderating Role of the Stakeholder Protection Context. Corporate Social Responsibility and Environmental Management, 23(5). https://doi.org/10.1002/csr.1379

Martínez-Ferrero, J., Suárez-Fernández, O., \& GarcíaSánchez, I. M. (2018). Obfuscation versus enhancement as corporate social responsibility disclosure strategies. Corporate Social Responsibility and Environmental Management, (September 2018), 468-480. https://doi.org/ 10.1002/csr.1697

Matisoff, D. C., Noonan, D. S., \& O’Brien, J. J. (2013). Convergence in environmental reporting: Assessing the carbon disclosure project. Business Strategy and the Environment, 22(5), 285-305. https://doi.org/10.1002/bse. 1741

Mazzi, F., Terzani, S., Baldini, M., Maso, L. D., \& Liberatore, G. (2016). Role of Country- and Firm-Level Determinants in Environmental, Social, and Governance Disclosure. Journal of Business Ethics, 150(1), 79-98. https: //doi.org/10.1007/s10551-016-3139-1

Meng, X. H., Zeng, S. X., Tam, C. M., \& Xu, X. D. (2013). Whether Top Executives' Turnover Influences Environmental Responsibility: From the Perspective of Environmental Information Disclosure. Journal of Business Ethics, 114(2), 341-353. https://doi.org/10.1007/ s10551-012-1351-1

Michelon, G., Pilonato, S., \& Ricceri, F. (2015). CSR reporting practices and the quality of disclosure: An empirical analysis. Critical Perspectives on Accounting, 33, 59-78. https://doi.org/10.1016/j.cpa.2014.10.003

Michelon, G., Patten, D. M., \& Romi, A. M. (2018). Creating Legitimacy for Sustainability Assurance Practices: Evidence from Sustainability Restatements. European Ac- 
counting Review, 8180(May), 1-28. https://doi.org/10. 1080/09638180.2018.1469424

Mio, C. (2010). Corporate social reporting in Italian multiutility companies: An empirical analysis. Corporate Social Responsibility and Environmental Management, 17(5), 247-271. https://doi.org/10.1002/csr.213

Miras Rodríguez, M.M., Carrasco Gallego, A. \& Escobar Pérez, B. (2014). Corporate social responsibility and financial performance: a meta-analysis. Spanish Journal of Finance and Accounting / Revista Española de Financiación y Contabilidad, 43(2), 193-215.

Mitchell, C. G., \& Hill, T. (2009). Corporate social and environmental reporting and the impact of internal environmental policy in South Africa. Corporate Social Responsibility and Environmental Management, 16(1), 4860. https://doi.org/10.1002/csr.179

Mohamed Adnan, S., Hay, D., \& van Staden, C. J. (2018). The influence of culture and corporate governance on corporate social responsibility disclosure: A cross country analysis. Journal of Cleaner Production, 198, 820-832. https://doi.org/10.1016/j.jclepro.2018.07.057

Moneva, J. M., \& LLena, F. (2000). Environmental disclosure in the annual reports of large companies in Portugal. European Accounting Review, 9(12), 7-29. https://doi. org/10.1080/0969160X.2005.9651739

Monteiro, S. \& Aibar-Guzmán, B. (2010). Determinants of environmental disclosure in the annual reports of large companies operating in Portugal. Corporate Social Responsibility and Environmental Management, 17(4), 185204.

Moratis, L., \& Brandt, S. (2017). Corporate stakeholder responsiveness? Exploring the state and quality of GRIbased stakeholder engagement disclosure of European firms. Corporate Social Responsibility and Environmental Management, 24(4), 312-325. https://doi.org/10.1002/ csr. 1408

Morhardt, J. E. (2010). Corporate Social Responsibility and Sustainability Reporting on the Internet. Business Strategy and the Environment Bus. Strat. Env, 19(July 2009), 436-452. https://doi.org/10.1002/bse.657

Mori Junior, R., \& Best, P. (2017). GRI G4 content index: Does it improve credibility and change the expectation-performance gap of GRI-assured sustainability reports? Sustainability Accounting, Management and Policy Journal, 8(5), 571-594. https://doi.org/10.1108/ SAMPJ-12-2015-0115

Moroney, R., \& Trotman, K. T. (2016). Differences in Auditors' Materiality Assessments When Auditing Financial Statements and Sustainability Reports. Contemporary Accounting Research, 33(2), 551-575. https://doi.org/10. 1111/1911-3846.12162

Moroney, R., Windsor, C., \& Aw, Y. T. (2012). Evidence of Assurance Enhancing the Quality of Voluntary Environmental Disclosure: Accouniting and Finance, 52, 903939. https://doi.org/10.1111/j.1467-629X.2011.00413.

Morrison, L., Wilmshurst, T., \& Shimeld, S. (2016). Environmental Reporting Through an Ethical Looking Glass. Journal of Business Ethics, (June 2015), 1-16. https: //doi.org/10.1007/s10551-016-3136-4

Moseñe, J. A., Burritt, R. L., Sanagustín, M. V., Moneva, J. M., \& Tingey-Holyoak, J. (2013). Environmental reporting in the Spanish wind energy sector: An institutional view. Journal of Cleaner Production, 40, 199-211. https://doi. org/10.1016/j.jclepro.2012.08.023

Moser, D. V., \& Martin, P. R. (2012). A broader perspective on corporate social responsibility research in accounting. Accounting Review, 87(3), 797-806. https://doi.org/10. 2308 /accr- 10257

Muhammad, bial F., \& De Villiers, C. (2019). The shaping of sustainability assurance through the competition between accounting and non-accounting providers. Accounting, Auditing \& Accountability Journal, 32(1), 307-336. https://doi.org/http://dx.doi.org/10.1108/ MRR-09-2015-0216

Murray, A., Sinclair, C. D., Power, D. M., \& Gray, R. (2006). Do financial markets care about social and environmental disclosure?: Further evidence and exploration from the UK. Accounting, Auditing and Accountability Journal, 19(2), 228-255. https://doi.org/10.1108/ 09574090910954864

Muslu, V., Mutlu, S., Radhakrishnan, S., \& Tsang, A. (2017). Corporate Social Responsibility Report Narratives and Analyst Forecast Accuracy. Journal of Business Ethics, 154(4), 1-24. https://doi.org/10.1007/ s10551-016-3429-7

Muttakin, M. B., Khan, A., \& Mihret, D. G. (2018). The Effect of Board Capital and CEO Power on Corporate Social Responsibility Disclosures. Journal of Business Ethics, 150(1), 41-56. https://doi.org/10.1007/ s10551-016-3105-y

Muttakin, M. B., Mihret, D. G., \& Khan, A. (2018). Corporate political connection and corporate social responsibility disclosures: A neo-pluralist hypothesis and empirical evidence. Accounting, Auditing \& Accountability Journal, 31(2), 725-744. https://doi.org/http://dx.doi. org/10.1108/MRR-09-2015-0216

Muttakin, M. B., \& Subramaniam, N. (2015). Firm ownership and board characteristics. Sustainability Accounting, Management and Policy Journal, 6(2), 138-165. https: //doi.org/10.1108/sampj-10-2013-0042

Ni, X., \& Zhang, H. (2019). Mandatory corporate social responsibility disclosure and dividend payouts: evidence from a quasi-natural experiment. Accounting \& Finance, 58(71802170), 1581-1612. https://doi.org/10.1111/ acfi. 12438

Noronha, C., Leung, T. C. H., \& Lei, O. I. (2015). Corporate social responsibility disclosure in Chinese railway companies. Sustainability Accounting, Management and Policy Journal, 6(4), 446-474. https://doi.org/10.1108/ sampj-09-2014-0057

Ntim, C. G., \& Soobaroyen, T. (2013). Black Economic Empowerment Disclosure by South African Listed Corporations: The Influence of Ownership and Board Characteristics. Journal of Business Ethics, 116(1), 121-138. https://doi.org/10.1007/s10551-012-1446-8

O'Donovan, G. (2002). Environmental disclosure in the annual report: Extending the applicability and predictive power of legitimacy theory. Accounting, Auditing and Accountability Journal, 15(3), 344-371. https://doi.org/ 10.1108/09574090910954864

O'Dwyer, B. (2011). The Case of Sustainability Assurance: Constructing a New Assurance Service. Contemporary Accounting Research, 28(4), 1230-1266. https://doi.org/ 10.1111/j.1911-3846.2011.01108.x

O’Dwyer, B., \& Owen, D. L. (2005). Assurance statement practice in environmental, social and sustainability reporting: A critical evaluation. British Accounting Review, 37(2), 205-229. https://doi.org/10.1016/j.bar.2005.01. 005

O’Dwyer, B., Owen, D., \& Unerman, J. (2011). Seeking legitimacy for new assurance forms: The case of assurance 
on sustainability reporting. Accounting, Organizations and Society, 36(1), 31-52. https://doi.org/10.1016/j. aos.2011.01.002

O’Dwyer, B., Unerman, J., \& Hession, E. (2005). User needs in sustainability reporting: Perspectives of stakeholders in Ireland. European Accounting Review, 14(4), 759-787. https://doi.org/10.1080/09638180500104766

Odriozola, M. D., \& Baraibar-Diez, E. (2017). Is Corporate Reputation Associated with Quality of CSR Reporting? Evidence from Spain. Corporate Social Responsibility and Environmental Management, 24(2), 121-132. https://doi.org/10.1002/csr.1399

Ott, C., Schiemann, F., \& Günther, T. (2017). Disentangling the determinants of the response and the publication decisions: The case of the Carbon Disclosure Project. Journal of Accounting and Public Policy, 36(1), 14-33. https://doi.org/10.1016/j.jaccpubpol.2016.11.003

Park, J., \& Brorson, T. (2005). Experiences of and views on third-party assurance of corporate environmental and sustainability reports. Journal of Cleaner Production, 13(1011), 1095-1106. https://doi.org/10.1016/j.jclepro.2004. 12.006

Pedersen, E. R. G., Neergaard, P., Pedersen, J. T., \& Gwozdz, W. (2013). Conformance and deviance: Company responses to institutional pressures for corporate social responsibility reporting. Business Strategy and the Environment, 22(6), 357-373. https://doi.org/10.1002/bse. 1743

Perego, P., \& Kolk, A. (2012). Multinationals' Accountability on Sustainability: The Evolution of Third-party Assurance of Sustainability Reports. Journal of Business Ethics, 110(2), 173-190. https://doi.org/10.1007/ s10551-012-1420-5

Pérez, A., García de los Salmones, M. del M., \& López, C. (2015). Corporate Reputation in The Spanish Context: An Interaction Between Reporting to Stakeholders and Industry. Journal of Business Ethics, 129(3), 733-746. https://doi.org/10.1007/s10551-014-2199-3

Peters, G. F., \& Romi, A. M. (2013). Does the Voluntary Adoption of Corporate Governance Mechanisms Improve Environmental Risk Disclosure? Evidence from Greenhouse Gas Emission Accounting. Journal of Business Ethics, 125(4), 637-666. https://doi.org/10.1007/ s10551-013-1886-9

Peters, G. F., \& Romi, A. M. (2015). The association between sustainability governance characteristics and the assurance of corporate sustainability reports. Auditing, 34(1), 163-198. https://doi.org/10.2308/ajpt-50849

Pflugrath, G., Roebuck, P., \& Simnett, R. (2011). Impact of assurance and assurer's professional affiliation on financial analysts' assessment of credibility of corporate social responsibility information. Auditing, 30(3), 239-254. https://doi.org/10.2308/ajpt-10047

Platonova, E., Asutay, M., Dixon, R., \& Mohammad, S. (2018). The Impact of Corporate Social Responsibility Disclosure on Financial Performance: Evidence from the GCC Islamic Banking Sector. Journal of Business Ethics, 151(2), 451-471. https://doi.org/10.1007/ s10551-016-3229-0

Plumlee, M., Brown, D., Hayes, R. M., \& Marshall, R. S. (2015). Voluntary environmental disclosure quality and firm value: Further evidence. Journal of Accounting and Public Policy, 34(4), 336-361. https://doi.org/10.1016/ j.jaccpubpol.2015.04.004

Prado Lorenzo, J. M., García Sánchez, I. M., \& Blázquez Zaballos, A. (2013). El impacto del sistema cultural en la transparencia corporativa. Revista Europea de Dirección y Economía de La Empresa, 22(3), 143-154. https: //doi.org/10.1016/j.redee.2013.04.001

Prado-Lorenzo, J. M., Gallego-Álvarez, I., \& García-Sánchez, I. M. (2009). Características del consejo de administración e información en materia de Responsabilidad Social Corporativa. Revista Espanola de Financiacion y Contabilidad, XXXVIII(141), 107-135.

Prado-Lorenzo, J.-M., \& Garcia-Sanchez, I.-M. (2010). The Role of the Board of Directors in Disseminating Relevant Information on Greenhouse Gases. Journal of Business Ethics, 97(3). https://doi.org/10.1007/ s10551-010-0515-0

Prado-Lorenzo, J.-M., Gallego-Alvarez, I., \& Garcia-Sanchez, I. M. (2009). Stakeholder engagement and corporate social responsibility reporting: The ownership structure effect. Corporate Social Responsibility and Environmental Management, 16(2). https://doi.org/10.1002/csr.189

Pucheta-Martínez, M. C., Bel-Oms, I., \& Nekhili, M. (2018). The contribution of financial entities to the sustainable development through the reporting of corporate social responsibility information. Sustainable Development, (September), 1-13. https://doi.org/10.1002/sd.1911

Pucheta-Martínez, M. C., Bel-Oms, I., \& Olcina-Sempere, G. (2018). Commitment of independent and institutional women directors to corporate social responsibility reporting. Business Ethics, (September 2017), 1-15. https: //doi.org/10.1111/beer.12218

Pucheta-Martínez, M. C., Bel-Oms, I., \& Rodrigues, L. L. (2019). The engagement of auditors in the reporting of corporate social responsibility information. Corporate Social Responsibility and Environmental Management, 26(1), 46-56. https://doi.org/10.1002/csr.1656

Pucheta-Martínez, M. C., \& Chiva-Ortells, C. (2018). The role of directors representing institutional ownership in sustainable development through corporate social responsibility reporting. Sustainable Development, 26(6), 835-846. https://doi.org/10.1002/sd.1853

Pucheta-Martínez, M. C., \& Gallego-Álvarez, I. (2018). Environmental reporting policy and corporate structures: An international analysis. Corporate Social Responsibility and Environmental Management, (December 2017), 111. https://doi.org/10.1002/csr.1494

Radu, C., \& Francoeur, C. (2017). Does Innovation Drive Environmental Disclosure? A New Insight into Sustainable Development. Business Strategy and the Environment, 26(7), 893-911. https://doi.org/10.1002/bse.1950

Ramos, T. B., Cecílio, T., Douglas, C. H., \& Caeiro, S. (2013). Corporate sustainability reporting and the relations with evaluation and management frameworks: The Portuguese case. Journal of Cleaner Production, 52, 317328. https://doi.org/10.1016/j.jclepro.2013.03.002

Rankin, M., Windsor, C., \& Wahyuni, D. (2011). Article information: An investigation of voluntary corporate greenhouse gas emissions reporting in a market governance system: Australian evidence. Accounting, Auditing and Accountability Journal, 24(8), 1037-1070. https://doi.org/ $10.1108 / 09574090910954864$

Raucci, D., \& Tarquinio, L. (2020). Sustainability Performance Indicators and Non-Financial Information Reporting. Evidence from the Italian Case. Administrative Sciences, 10 (1), 13 https://doi.org/10.3390/admsci10010013

Reimsbach, D., \& Hahn, R. (2015). The effects of negative incidents in sustainability reporting on investors' judgments-an experimental study of third-party versus self-disclosure in the realm of sustainable development. 
Business Strategy and the Environment, 24(4), 217-235. https://doi.org/10.1002/bse.1816

Reimsbach, D., Hahn, R., \& Gürtürk, A. (2017). Integrated Reporting and Assurance of Sustainability Information: An Experimental Study on Professional Investors' Information Processing. European Accounting Review, 1-23. https://doi.org/10.1080/09638180.2016.1273787

Reverte, C. (2009). Determinants of corporate social responsibility disclosure ratings by Spanish listed firms. Journal of Business Ethics, 88(2), 351-366. https://doi.org/10. 1007/s10551-008-9968-9

Rezaee, Z., \& Tuo, L. (2017). Are the Quantity and Quality of Sustainability Disclosure Associated with the Innate and Discretionary Earnings Quality? Journal of Business Ethics, 1-24. https://doi.org/10.1007/s10551-017-3546-y

Rivière-Giordano, G., Giordano-Spring, S., \& Cho, C. H. (2018). Does the level of assurance statement on environmental disclosure affect investor assessment?: An experimental study. Sustainability Accounting, Management and Policy Journal, 9(3), 336-360. https://doi.org/10. 1108/SAMPJ-03-2018-0054

Rodrigue, M. (2014). Contrasting realities: corporate environmental disclosure and stakeholder-released information. Accounting, Auditing \& Accountability Journal, 27(1), 119-149. https://doi.org/10.1108/ AAAJ-04-2013-1305

Rodrigues, M., \& Mendes, L. (2018). Mapping of the literature on social responsibility in the mining industry: A systematic literature review. Journal of Cleaner Production, 181, 88-101. https://doi.org/10.1016/j.jclepro.2018.01. 163

Rodríguez-Gómez, S., Arco-Castro, M.L., Lopez-Perez, M.V., \& Rodríguez-Ariza, L. (2020). Where Does CSR Come from and Where Does It Go? A Review of the State of the Art. Administrative Sciences, 10 (3), 60; https:/ /doi.org/ 10.3390/admsci10030060

Rodríguez-Ariza, L., Frías Aceituno, J. V., \& García Rubio, R. (2014). El consejo de administración y las memorias de sostenibilidad. Revista de Contabilidad, 17(1), 5-16. https://doi.org/10.1016/j.rcsar.2013.02.002

Romolini, A., Fissi, S., \& Gori, E. (2014). Scoring CSR reporting in listed companies - evidence from Italian best practices. Corporate Social Responsibility and Environmental Management, 21(2), 65-81. https://doi.org/10. 1002/csr.1299

Rosati, F., \& Faria, L. G. D. (2019a). Addressing the SDGs in sustainability reports: The relationship with institutional factors. Journal of Cleaner Production, 215, 1312-1326. https://doi.org/10.1016/j.jclepro.2018.12.107

Rosati, F., \& Faria, L. G. D. (2019b). Business contribution to the Sustainable Development Agenda: Organizational factors related to early adoption of SDG reporting. Corporate Social Responsibility and Environmental Management, (June 2018), 1-10. https://doi.org/10.1002/csr. 1705

Russo-Spena, T., Tregua, M., \& de Chiara, A. (2016). Trends and Drivers in CSR Disclosure: A Focus on Reporting Practices in the Automotive Industry. Journal of Business Ethics, 1-16. https://doi.org/10.1007/s10551-016-3235-2

Saenz, C., \& Brown, H. (2018). The disclosure of anticorruption aspects in companies of the construction sector: Main companies worldwide and in Latin America. Journal of Cleaner Production, 196, 259-272. https:// doi.org/10.1016/j.jclepro.2018.06.045

Sankara, J., Patten, D. M., \& Lindberg, D. L. (2019). Mandated social disclosure. Sustainability Accounting, Man- agement and Policy Journal, 10(1), 208-228. https://doi. org/10.1108/SAMPJ-05-2017-0046

Secchi, D. (2006). The Italian experience in social reporting: An empirical analysis. Corporate Social Responsibility and Environmental Management, 13(3), 135-149. https://doi.org/10.1002/csr.96

Sethi, S. P., Martell, T. F., \& Demir, M. (2017a). Enhancing the Role and Effectiveness of Corporate Social Responsibility (CSR) Reports: The Missing Element of Content Verification and Integrity Assurance. Journal of Business Ethics, 144(1), 59-82. https://doi.org/10.1007/ s10551-015-2862-3

Sethi, S. P., Martell, T. F., \& Demir, M. (2017b). An Evaluation of the Quality of Corporate Social Responsibility Reports by Some of the World's Largest Financial Institutions. Journal of Business Ethics, 140(4), 787-805. https://doi.org/10.1007/s10551-015-2878-8

Shabana, K. M., Buchholtz, A. K., \& Carroll, A. B. (2016). The Institutionalization of Corporate Social Responsibility Reporting. Business \& Society, 1-29. https://doi.org/10. $1177 / 0007650316628177$

Shafer, W. E., \& Lucianetti, L. (2018). Machiavellianism, stakeholder orientation, and support for sustainability reporting. Business Ethics, 27(3), 272-285. https://doi. org/10.1111/beer.12187

Sharif Mahmud Khalid, Atkins, J., \& Barone, E. (2019). Sartrean bad-faith? Site-specific social, ethical and environmental disclosures by multinational mining companiesArticle information: Accounting, Auditing \& Accountability Journal, 32(1), 55-74. https://doi.org/http://dx. doi.org/10.1108/MRR-09-2015-0216

Sierra, L., Zorio, A., \& García-Benau, M. A. (2013). Sustainable Development and Assurance of Corporate Social Responsibility Reports Published by Ibex-35 Companies. Corporate Social Responsibility and Environmental Management, 20(6), 359-370. https://doi.org/10.1002/csr. 1303

Sierra-García, L., Zorio-Grima, A., \& García-Benau, M. A. (2015). Stakeholder Engagement, Corporate Social Responsibility and Integrated Reporting: An Exploratory Study. Corporate Social Responsibility and Environmental Management, 22(5), 286-304. https://doi.org/ 10.1002/csr. 1345

Simnett, R., Carson, E., \& Vanstraelen, A. (2016). International archival auditing and assurance research: Trends, methodological issues, and opportunities. Auditing, 35(3), 1-32. https://doi.org/10.2308/ajpt-51377

Skouloudis, A., Malesios, C., \& Dimitrakopoulos, P. G. (2019). Corporate biodiversity accounting and reporting in megadiverse countries: An examination of indicators disclosed in sustainability reports. Ecological Indicators, 98(January), 888-901. https://doi.org/10.1016/j.ecolind.2018. 11.060

Smith, T., Paavola, J., \& Holmes, G. (2019). Corporate reporting and conservation realities: Understanding differences in what businesses say and do regarding biodiversity. Environmental Policy and Governance, 29(1), 313. https://doi.org/10.1002/eet.1839

Solomon, J. F., \& Solomon, A. (2006). Private social, ethical and environmental disclosure. Accounting, Auditing and Accountability Journal, 19(4), 564-591. https://doi.org/ 10.1108/09574090910954864

Solomon, J. F., Solomon, A., Norton, S. D., \& Joseph, N. (2011). Private climate change reporting: an emerging discourse of risk and opportunity? Accounting, Auditing 
and Accountability Journal, 24(8), 1119-1148.

Sotorrío, L. L., \& Sánchez, J. L. F. (2010). Corporate social reporting for different audiences: The case of multinational corporations in Spain. Corporate Social Responsibility and Environmental Management, 17(5), 272-283. https://doi.org/10.1002/csr.215

Spence, C. (2009). Social and Environmental Reporting and the Corporate Ego. Business Strategy and the Environment, 18, 254-265.

Steinmeier, M., \& Stich, M. (2017). Does Sustainability Assurance Improve Managerial Investment Decisions? European Accounting Review, 8180, 1-33. https://doi. org/10.1080/09638180.2017.1412337

Talbot, D., \& Boiral, O. (2015a). GHG Reporting and Impression Management: An Assessment of Sustainability Reports from the Energy Sector. Journal of Business Ethics, 147(2), 1-17. https://doi.org/10.1007/ s10551-015-2979-4

Talbot, D., \& Boiral, O. (2015b). Strategies for Climate Change and Impression Management: A Case Study Among Canada's Large Industrial Emitters. Journal of Business Ethics, 132(2), 329-346. https://doi.org/10. 1007/s10551-014-2322-5

Tang, S., \& Demeritt, D. (2017). Climate Change and Mandatory Carbon Reporting: Impacts on Business Process and Performance. Business Strategy and the Environment. https://doi.org/10.1002/bse.1985

Tauringana, V., \& Chithambo, L. (2015). The effect of DEFRA guidance on greenhouse gas disclosure. British Accounting Review, 47(4), 425-444. https://doi.org/10.1016/j. bar.2014.07.002

Thijssens, T., Bollen, L., \& Hassink, H. (2015). Secondary Stakeholder Influence on CSR Disclosure: An Application of Stakeholder Salience Theory. Journal of Business Ethics, 132(4), 873-891. https://doi.org/10.1007/ s10551-015-2623-3

Thorne, L., Mahoney, L. S., \& Manetti, G. (2014). Motivations for issuing standalone CSR reports: a survey of Canadian firms. Accounting, Auditing and Accountability Journal, 27(4), 686-714. https://doi.org/10.1108/ 09574090910954864

Trotman, A. J., \& Trotman, K. T. (2015). Internal audit's role in GHG emissions and energy reporting: Evidence from audit committees, senior accountants, and internal auditors. Auditing, 34(1), 199-230. https://doi.org/10.2308/ ajpt-50675

Uddin, S., Siddiqui, J., \& Islam, M. A. (2018). Corporate Social Responsibility Disclosures, Traditionalism and Politics: A Story from a Traditional Setting. Journal of Business Ethics, 151(2), 409-428. https://doi.org/10.1007/ s10551-016-3214-7

Vaz Ogando, N., Ruiz Blanco, S., \& Fernandez-Feijoo Souto, B. (2018). The assurance market of sustainability reports in Spain: An analysis from the demand perspective. Revista de Contabilidad, 21(1), 48-62. https://doi.org/10.1016/ j.rcsar.2017.07.003

Vigneau, L., Humphreys, M., \& Moon, J. (2015). How Do Firms Comply with International Sustainability Standards? Processes and Consequences of Adopting the Global Reporting Initiative. Journal of Business Ethics, 131(2), 469-486. https://doi.org/10.1007/ s10551-014-2278-5

Wang, X., Cao, F., \& Ye, K. (2018). Mandatory Corporate Social Responsibility (CSR) Reporting and Financial Reporting Quality: Evidence from a Quasi-Natural Experiment. Journal of Business Ethics, 152(1), 253-274. https://doi.org/10.1007/s10551-016-3296-2

Wang, Z., Hsieh, T. S., \& Sarkis, J. (2018). CSR Performance and the Readability of CSR Reports: Too Good to be True? Corporate Social Responsibility and Environmental Management, 25(1), 66-79. https://doi.org/10. 1002/csr.1440

Wang, Z., Reimsbach, D., \& Braam, G. (2018). Political embeddedness and the diffusion of corporate social responsibility practices in China: A trade-off between financial and CSR performance? Journal of Cleaner Production, 198, 1185-1197. https://doi.org/10.1016/j.jclepro. 2018.07.116

Weber, O. (2014). Environmental, social and governance reporting in China. Business Strategy and the Environment, 23(5), 303-317. https://doi.org/10.1002/bse.1785

Yang, H. H., Craig, R., \& Farley, A. (2015). A review of Chinese and English language studies on corporate environmental reporting in China. Critical Perspectives on Accounting, 28, 30-48. https://doi.org/10.1016/j.cpa. 2014.10.001

Young, S., \& Marais, M. (2012). A Multi-level Perspective of CSR Reporting: The Implications of National Institutions and Industry Risk Characteristics. Corporate Governance: An International Review, 20(5), 432-450. https://doi.org/10.1111/j.1467-8683.2012.00926.x

Yu, H. C., Kuo, L., \& Kao, M. F. (2017). The relationship between CSR disclosure and competitive advantage. Sustainability Accounting, Management and Policy Journal, 8(5), 547-570. https://doi.org/10.1108/ SAMPJ-11-2016-0086

Yu, W., \& Zheng, Y. (2018). The disclosure of corporate social responsibility reports and sales performance in China. Accounting and Finance, (16). https://doi.org/10.1111/ acfi. 12431

Yusoff, H., Othman, R., \& Yatim, N. (2014). Culture and accountants' perceptions of environmental reporting practice. Business Strategy and the Environment, 23(7), 433446. https://doi.org/10.1002/bse.1793

Zamora-Ramírez, C., González-González, J. M., \& María Sabater-Marcos, A. (2016). Carbon Reporting: análisis de la respuesta del mercado español. Spanish Journal of Finance and Accounting / Revista Española de Financiación y Contabilidad, 45(2), 231-265. https://doi. org/10.1080/02102412.2016.1162972

Zeng, S. X., Xu, X. D., Yin, H. T., \& Tam, C. M. (2012). Factors that Drive Chinese Listed Companies in Voluntary Disclosure of Environmental Information. Journal of Business Ethics, 109(3), 309-321. https://doi.org/10.1007/ s10551-011-1129-X

Zhou, S., Simnett, R., \& Green, W. J. (2016). Assuring a new market: The interplay between country-level and company-level factors on the demand for greenhouse gas (GHG) information assurance and the choice of assurance provider. Auditing, 35(3), 141-168. https://doi.org/10. 2308/ajpt-51414

Zorio, A., García-Benau, M. A., \& Sierra, L. (2013). Sustainability development and the quality of assurance reports: Empirical evidence. Business Strategy and the Environment, 22(7), 484-500. https://doi.org/10.1002/ bse. 1764 